\title{
Assessment of local competitiveness: A composite indicator analysis of Costa Rican counties using the 'Benefit of the Doubt' model
}

\author{
Esteban Lafuente \\ Department of Management, Universitat Politècnica de Catalunya (UPC BarcelonaTech) \\ EPSEB, Av. Gregorio Marañón 44-50, 08028 Barcelona, Spain \\ E-mail: esteban.lafuente@upc.edu \\ Manuel Araya \\ Costa Rica Institute of Technology. Business School. Campus Cartago. \\ Business School, 15th Street, 14th Avenue, Cartago, Costa Rica \\ E-mail: maraya@orosigold.com \\ Juan Carlos Leiva \\ Costa Rica Institute of Technology. Business School. Campus Cartago. \\ Business School, 15th Street, 14th Avenue, Cartago, Costa Rica \\ E-mail: jleiva@itcr.ac.cr
}

\begin{abstract}
This study employs a Benefit-of-the-Doubt (BOD) weighting model that incorporates information generated via a participatory method-i.e., based on experts' opinion - to construct a composite indicator that evaluates the competitiveness level of Costa Rican counties during 20102016. The results of the empirical application based on the county competitiveness index (CCI) reveal the superior informative power of the proposed BOD composite indicator, relative to models using equal weight restrictions or weights estimated via principal component analysis. The county competitiveness index is a valuable tool to monitor counties' competitive level, and the findings underline that an analysis based on the BOD approach may offer useful information to policy makers on what strategic actions may potentially optimize the allocation of local resources and, subsequently, enhance economic outcomes (i.e., business creation and employment).
\end{abstract}

Keywords: Composite indicators, DEA, benefit of the doubt, counties, Costa Rica

JEL classification: C14, C43, C61, R58

Working Paper version: March 2020

\section{PLEASE CITE AS:}

Lafuente, E., Araya, M., Leiva, J.C. (2020). Assessment of local competitiveness: A composite indicator analysis of Costa Rican counties using the 'Benefit of the Doubt' model. Socio-Economic Planning Sciences, in press, doi: https://doi.org/10.1016/j.seps.2020.100864 


\section{Assessment of local competitiveness: A composite indicator analysis of Costa Rican counties using the 'Benefit of the Doubt' model}

\section{Introduction}

This study deals with the scrutiny of index numbers designed to analyze counties' competitiveness level. From an economic perspective, it is unquestionable that competitive and well-functioning territories offer better conditions for achieving other, equally relevant outcomes with important societal implications. The growing awareness of the importance of territorial efficiency as key pillar for economic consolidation has translated into a large stock of scientific work analyzing different aspects of territorial performance (see, e.g., Balaguer-Coll et al. 2007; Cherchye et al., 2008; Lin et al., 2011; Calcagnini and Perugini, 2018; Karagiannis and Karagiannis, 2018). In parallel, governing bodies have recently proposed specific measures aimed at stimulating territorial competitiveness (e.g., European Commission, 2017; OECD, 2017).

Because of the importance of accurately evaluating territories' environmental conditions from multiple angles - e.g., human capital level of the population, digital infrastructures or economic conditions - the development of policy controls and support metrics seems necessary to generate valuable information that can be used by policy makers for implementing more effective policies.

In this sense, composite indicators (CIs) are increasingly recognized as an instrumental tool for policy making, By compiling multiple variables into a single index, CIs permit to rank the analyzed units for comparison purposes as well as for setting policy priorities (Cherchye et al., 2007). Also, CIs constitute an alternative to the excess of statistics that often generate recommendations based on complex regression models with limited practical applicability that neglect the multidimensionality of the phenomena that CIs pursue to quantify (Leontief, 1971; Friedman and Schwartz, 1991).

Composite indicators are increasingly relevant for scholars and policy observers in their attempts to identifying policies that help to fully realize the objective of enhanced competitiveness.

In this sense, the scrutiny of composite indicators designed to monitor counties' competitiveness is the focus of this study. In the context of this study it is relevant to question, how would the analysis of local competitive conditions based on CIs differ when the configuration of its sub-indicators (i.e., endogenous weights) is taken into consideration? Moreover, and because the relative importance of the different sub-indicators that form the focal counties' competitiveness index varies across territories, does the proposed county-level competitiveness analysis help to unveil competitiveness trajectories that can be used to formulate relevant support policies, linked for instance to business creation and employment figures? 
To answer these questions empirically, the main purpose of this study is to evaluate a composite indicator designed to measure the competitiveness level of Costa Rican counties (county's competitiveness index, hereafter CCI, developed by Ulate et al. (2012)).

At this point, it should be noted that underlying most CIs is the unrealistic presumption that the individual contribution of all variables is equally important to shaping the composite indicator (equal weights). This property obscures CI analyses by ignoring territorial heterogeneity, in terms of, for example, infrastructures, production factors availability, or local policies.

In order to correct this property of the CCI, the empirical application employs a 'Benefit of the Doubt' (BOD) model (Cherchye et al., 2007) that incorporates information generated by a participatory method—i.e., based on experts' opinion—in order to construct a composite indicator that produces reliable estimations on the competitiveness level of Costa Rican counties.

The BOD weighting, named after Melyn and Moesen (1991) and further developed by, among others, Cherchye et al. (2007), Sahoo et al. (2017) and Karagiannis and Karagiannis (2018), is among the optimization methods suggested by the OECD (2008) for computing composite indicators. By employing the 'Benefit of the Doubt' (BOD) model rooted in non-parametric techniques (Data Envelopment Analysis, DEA), the proposed analysis focuses on the efficiency assessment of counties from a developing setting, namely Costa Rica during the period 2010-2016.

Costa Rica is an attractive setting for various reasons. First, the positive evolution of Costa Rican figures during the last three decades, in terms of economic performance (GDP per head at PPP = 7787 US\$ in 1991 and 14374 US\$ in 2016) and other, equally relevant social goals (virtually universal access to healthcare, strong education system, low infant mortality and high life expectancy), have been acknowledged (OECD, 2018). Second, the country's economic performance and competitiveness is atop of the Latin American region, jointly with Chile (OECD, 2016), and this contributed to obtain in 2015 the approval of the OECD for setting out the roadmap for Costa Rica’s accession to the OECD (OECD, 2015). Third, Costa Rica’s economic strategy has encouraged the diversification of productive activities, which has translated into the consolidation of manufacturing sectors, high-tech electronic products and, more recently, the medical industry (medical devices and instruments) (Alonso and Leiva, 2019; Araya, 2019). As a result, exports account for $32.80 \%$ of the country's GDP in 2016; as compared to the average of $27.90 \%$ for OECD member countries (OECD, 2016). Additionally, the greater involvement of Costa Rican businesses in global value chains has led to the rise of exports of business services, in particular, knowledge-based informatics and information services (Lafuente, et al., 2018).

The importance of this study stretches beyond a purely computational exercise and has implications within the area of territorial performance. By incorporating ex-ante endogenous 
weights in the proposed BOD model, we contribute to unveil counties' policy priorities, which, in turn, have the potential to show policy makers how to orchestrate resources to fully materialize the benefits from superior local competitive conditions. By correlating counties' competitive efficiency with variations in both the stock of businesses and employment in a developing context, our study also helps to grasp how local environmental conditions impact territorial economic outcomes.

The remainder of the paper is organized as follows. Section 2 describes the structure of the composite indicator analyzed in this study (county competitiveness index, CCI). Section 3presents the data and method. The empirical results are presented in Section 4, while the concluding remarks, policy implications and future research avenues are discussed in Section 5.

\section{Quality of the local environment in Costa Rica: County competitiveness index (CCI)}

The County Competitiveness Index (CCI), developed by Ulate et al. (2012), is a composite indicator that measures the relative competitive performance of Costa Rican counties. The main objective of the CCI is to aggregate a number of variables connected to different county's stakeholders, including businesses, households and the local administration (Ulate et al., 2016).

The CCI includes 37 variables that are grouped into seven pillars linked to the local economic environment, local administration (governance), physical and digital infrastructures, local business environment, human capital, innovative capacities, and quality of life (Ulate et al., 2012; Araya, 2019). Table A1 in the Appendix presents the variables used to compute the seven pillars that make up the CCI. The description of the seven pillars included in the CCI follows.

Economic environment.- The proximity to a large and growing market is an important variable that explain the concentration of economic activity and the greater productivity of regions. The benefits derived from the access to larger markets are associated with relatively lower transportation costs, but also with an increased availability and variety of goods, services and productive inputs. To monitor the dynamism and access to a local and external market, the following variables were included: the growth rate of electricity consumption, municipal expenditures per capita (municipal expenditures minus local government investment), square meters of construction per Km2, and exports per worker. Keep in mind that information on other relevant economic variables is not available from the databases provided by the Costa Rican government to compute the CCI (e.g., the flow of transactions between counties).

Local administration.-At county level, Costa Rican municipalities enjoy fiscal, administrative and regulatory autonomy. Local administrations are empowered for creating, modifying, exonerating or eliminating municipal taxes. From the administrative point of view, municipalities set budgets, specific support programs and local development plans. Also, municipalities coordinate 
and manage the authorizations to develop specific investments (i.e., infrastructures subject to the central government's approval), as well as the promotion of support plans linked to public services (e.g., water plants). Two variables were included to measure counties’ performance: local government's economic capacity (measured by income per capita) and the degree of dependence on central government transfers (public sector transfers divided by municipality income). The capacity of municipalities to manage local goods and services is measured by the ratio of non-administrative expenditure per capita and the ratio of expenditure on the road network per Km2. The efficiency in responding to the innovative-led demands of local agents is measured by the number of days to obtain a commercial permit, which is obtained from a direct survey to all municipalities.

In 1998, a legislative reform was enforced in order to give greater political autonomy to municipalities. Electoral processes are important in Costa Rica, and the CCI index includes the citizens' participation in municipal and presidential elections as a variable that measures how much county citizens exercise their political rights. Finally, the ratio of the number of environmental impact evaluations divided by the number of construction permits granted by the municipality accounts for the degree of environmental complexity of the permits processed by municipalities.

Physical and digital infrastructures.-This pillar evaluates the county's infrastructures, in terms of mobility, communications and information technologies. The ratio of paved road network $(\mathrm{Km}$.) divided by the total road network $(\mathrm{Km}$.) measures the quality of road infrastructures (mobility). The availability of electricity and drinking water are basic factors for the location of both households and businesses. Also, this pillar introduces four variables to quantify the access to electricity, fixed telephone networks as well as to new information technologies: the percentage of households with access to Internet, the coverage and quality of the cell-phone network (2G and 3G mobile, and 3G global download performance). Note that in 2016 the last three variables were updated to account for the coverage and availability of the latest technologies (4G).

Business environment.-This pillar includes variables related to the complexity of the local economic environment. The competence variable measures, at county level, the access to labor for manufacturing and service-oriented companies. This variable compares the rate of potential employees (economically active population) in these sectors (manufacturing and services) at county and national level and values greater than unity indicate greater labor availability in the county. This variable is an adaptation of the competence indicator developed by Glaeser et al. (1992, p. 1142). The proximity to other economic agents improves productivity and relations with the rest of the country. Likewise, the diversity of the economic activities carried out within the county facilitates the exchange and increases the potential benefits from the externalities that counties can generate. The variable number of financial institutions (branches) per Km2 allows to quantifying the access to 
financial services. To measure the diversity of the county's economic activity, this pillar introduces a Herfindahl index based on the data made available by the Costa Rican Institute of Statistics (INEC, Directory of Business Establishments). The relative importance of exporting companies is measured by the proportion of exporting businesses in the county.

Human capital.-This pillar includes six variables. A group of three variables measures the educational potential of the workforce: coverage of English in elementary schools, the rate of enrolment in secondary and tertiary education (public universities). The fourth variable measures the size of the labor market via the economically active population (people aged between 16 and 65 years old) at county level. The fifth variable measures the skills of the county's labor pool by computing the proportion of workers in non-agricultural sectors, that is, manufacturing, construction and service activities (e.g., shops, hotels, education). Higher values for this variable point to a concentration of specialized workers. Finally, the sixth variable measures the dynamism of the local demand for formal employment by monitoring the growth of formal employment with respect to the variation of the economically active population within the county.

Innovation.- This pillar seeks to measure the county’ potential to disseminate, transfer and manage complex knowledge that can be eventually applied to production processes. This pillar includes three variables. First, the rate of exports in high-tech sectors relative to total exports which captures the weight of exports that originate from advanced knowledge applied to production processes and that are offered to foreign markets. The second and third variables aim at quantifying the capacity of the local labor pool to acquire, process, and benefit from the externalities associated with the exploitation of knowledge-based resources. These variables are the enrollment in science and technology degrees (in public universities) for county residents, and the rate of elementary schools, high school and university centers with access to Internet in the county.

Quality of life.-The six variables included in this pillar seek to measure standards of living. The first variable refers to residents' health measured by the mortality rate due to infections per 10thousand inhabitants. The second variable-i.e., number of recreation and entertainment establishments per 10-thousand inhabitants-measures county's amenities. The pillar includes two variables that measure crime: the rate of homicides per 100-thousand inhabitants, and the rate of robberies per 10-thousand inhabitants. The fifth variable, number of inhabitants per primary health center (EBAIS), is a proxy variable for the access to health services. The sixth variable deals with the municipality's environmental efforts (e.g., environmental action plans, recycling programs).

Rather than explaining the causes of counties' competitiveness, the CCI seeks to reveal the outcomes resulting from the decisions made by multiple actors. From a policy perspective, the monitoring of counties' relative performance permits to formulate relevant support measures as well 
as to establish priorities with the objective to promote local development. The analysis based on the County Competitiveness Index (CCI) shows the relative position of each county with respect to the rest of counties in each pillar included in the analysis (Ulate et al., 2016; Araya, 2019).

\section{Data and method}

\subsection{Data: County competitiveness index (CCI)}

The County Competitiveness Index (CCI) was specifically developed by the Observatory of Development and the School of Economics of the University of Costa Rica to measure the quality of the local environment of the 81 Costa Rican counties (Ulate et al., 2012 and 2016). The CCI is a composite indicator (index number) focused on the relative competitive performance of Costa Rican counties, and its main objective is to aggregate a number of variables connected to different municipalities' stakeholders, including businesses, households and the local administration (Ulate et al., 2012). The CCI is a good proxy variable to quantify differences in regional attractiveness and local environmental conditions. The CCI includes 37 variables that are grouped into seven pillars (y): (1) economic environment, (2) local administration, (3) physical and digital infrastructures, (4) business environment, (5) human capital, (6) innovative capacities, and (7) quality of life.

The variables included in the CCI have different measurement scales so, therefore, their values are standardized in the $[0,1]$ range (Ulate et al., 2012). The standardized variables are then averaged to compute the seven pillars of the CCI. Finally, for each county (i) the value of the County Competitiveness Index (CCI) is obtained as the arithmetic mean of the seven pillars $\left(C C I_{i}=\sum w_{k} y_{k i} \forall w_{k}=1 / 7\right)$.

Descriptive statistics for the CCI and its seven sub-pillars are presented in Table 1, while Table 2 shows CCI values for the seven Costa Rican provinces. As it can be noticed in Table 1, small differences can be found in the average regional competitiveness between 2010 and 2016, which is compatible with the notion that significant changes in the regional institutional setting take time. Also, we report a small decrease in the general county-level competitiveness between 2010 and 2016. Finally, from Figure 1 we note that counties located in the central part of the country-i.e., urban agglomerations in the provinces of Alajuela, Cartago, Heredia, and the capital San Joséconsistently show high levels of competitiveness.

--- Insert Table 1 and Figure 1 about here ---

In line with the analyses presented in this section and in Section 2, one would be tempted to question whether the selected variables (Table A1 in the Appendix) measure the corresponding 
competitive pillars, and whether the analyzed pillars accurately represent the counties’ competitiveness construct. To further corroborate the appropriateness of the variable selection process, a first robustness check was carried out based on the estimation of a principal component factor analysis that evaluates how well the 37 observed variables reflect the seven pillars that form the county competitiveness index (CCI). Results in Table A2 of the Appendix reveal that the reliability test (Cronbach’s alpha) for the seven competitiveness pillars ranges between 0.6402 ('Local economy') and 0.8756 ('Physical and digital infrastructures'). This result confirms that the constructs extracted from the factor models are internally consistent across the analyzed variables to measure the competitive pillars under evaluation (Nunnally and Bernstein, 1994). A second factor model corroborates that the seven competitive pillars efficiently measure the competitiveness construct at county level (Table A2: Cronbach’s alpha $=0.7627$ ).

\subsection{Assessment of county competitiveness via the Benefit of the Doubt (BOD) weighting}

We argue that county competitiveness is more connected to economic agents (i.e., individuals, businesses, and public administrations) functioning in local settings with better institutions and environmental conditions. In our view the aggregation method chosen to compute the CCI

$\left(C C I_{i}=\sum w_{k} y_{k i} \forall w_{k}=1 / 7\right)$ imposes important restrictions that can produce biased results when it comes to evaluate counties' competitiveness level. In this sense, the assumption that the seven CCI sub-indicators are equally important goes against the arguments that resources are heterogeneously distributed across territories (e.g., Lafuente et al., 2019), and that the relevance of the sub-indexes varies across territories (Cherchye et al., 2008; Karagiannis and Karagiannis, 2019).

This is the core of this study. The analysis proposed in this study seeks to evaluate the competitive level of Costa Rican counties as well as their strengths and weaknesses with the objective to identify potentially optimal competitiveness-enhancing policies at county level.

To construct the proposed composite indicator we employ the benefit-of-the-doubt (BOD) model (e.g., Cherchye et al., 2007). Rooted in non-parametric data envelopment analysis (DEA) techniques (for a survey on DEA see, e.g., Cooper et al. (2011)), the BOD weighting is among the methods suggested by the OECD (2008) for computing composite indicators (CIs). The BOD model, originally proposed by Melyn and Moesen (1991) and further developed by, among others, Cherchye et al. (2007), Sahoo et al. (2017) and Karagiannis and Karagiannis (2018), is a special case of the input-oriented DEA model (Charnes et al., 1978) with a single constant input (vector of 1s) (Lovell and Pastor, 1999; Despotis, 2005; Karagiannis and Lovell, 2016). 
Formally, for the 81 Costa Rican counties $(i=1, \ldots, \mathrm{N}=81)$, the BOD weighting model used in this study considers the seven sub-pillars $\left(\mathbf{y}=y_{1}, \ldots, y_{k} \wedge K=7\right)$ that form the CCI , and employs a set of endogenous weights (w) to compute the weighted average of the seven indicators (y) that maximize the CCI score for each county. The following linear program solves the BOD weighting problem and computes the optimal CCI value for each county (i):

$$
C C I_{i}^{B O D}=\max _{w, k} \sum_{k=1}^{K} w_{i k} y_{i k} \quad k=1, \ldots, K=7, \quad i=1, \ldots, N=81
$$

subject to :

$$
\sum_{k=1}^{K} w_{i k} y_{i k} \leq 1
$$

$w_{i k} \geq 0$

$$
L_{k} \leq \frac{w_{i k} y_{i k}}{\sum_{k=1}^{K} w_{i k} y_{i k}} \leq U_{k}
$$

Equation (1) computes for each county a vector of endogenous weights for the seven pillars $\left(w_{k}=w_{1}, \ldots, w_{7}\right)$ that maximizes the value of the CCI. The optimal CCI performance value is bounded $\left(\mathrm{CCI}_{i}^{B O D} \leq 1\right)$. For efficient counties on the frontier $\mathrm{CCI}_{i}^{B O D}=1$, while for inefficient territories $\mathrm{CCI}_{i}^{B O D}<1$ and $1-\mathrm{CCI}_{i}^{B O D}$ is the degree of inefficiency (i.e., the output expansion required to reach the frontier). Two aspects of the proposed BOD model (equation (1)) are worth mentioning. First, weights are constrained to be non-negative, which makes the composite indicator a non-decreasing function of the output set. The non-negativity constraint on the weights allows for extreme scenarios that render assessments of the results inaccurate (e.g., high number of artificially efficient counties). Therefore, additional restrictions on the weights are needed in order to take into consideration the relative importance of all CCI sub-indicators. For the purposes of this study, we added to equation (1) a 'pie share' restriction (Cherchye et al., 2007): $L_{k} \leq \frac{w_{i k} y_{i k}}{\sum_{k=1}^{K} w_{i k} y_{i k}} \leq U_{k}$. This type of proportional restriction is attractive because pie shares $\left(w_{i k} y_{i k}\right)$ do not depend on measurement units and they directly reveal the individual contribution of each pie share to the CCI, while allowing for weight heterogeneity within and between territories. In equation (1), $L_{k}$ and $U_{k}$ are the lower and upper limit set for each pie share, respectively. Note that the endogenous weights are county-specific and the sum of the pie shares equals the $\mathrm{CCI}$ score $\left(\mathrm{CCI}_{i}^{B O D}\right)$ (equation (1)). 
In a closely related manner, the second issue deals with the degree of importance-i.e., weights and limits $\left(L_{k}\right.$ and $U_{k}$ ) —assigned to the CCI sub-indicators. Instead of employing a set of homogeneous ex-post weights resulting from the optimization model in equation (1), the weights of the CCI sub-indicators were generated via participatory methods (Karagiannis and Karagiannis, 2019). More concretely, information on the weights for the seven CCI sub-indexes was obtained from the application of a 'budget allocation procedure', in which a group of experts was requested to allocate 100 points to the seven CCI sub-indexes. In line with the 'trade-off interpretation' proposed by Freudenberg (2003, p. 10), the interviewed individuals were specifically asked to assign more points to a sub-indicator the more important it is.

In order to capture different views on counties' competitiveness, we contacted experts from different stakeholder groups, including scholars, and public servants working for municipalities and other country-wide administrations promoting counties' competitiveness. The information was collected between July and September 2019 through telephone and face-to-face interviews conducted by one of the authors. We initially contacted 53 experts and, after two follow-up reminders, the final sample includes data for 26 experts: two academics (University of Costa Rica), one Director of the Costa Rica Office of Municipality Development (IFAM: www.ifam.go.cr), and 23 public servants working for 21 municipalities in different strategic positions (e.g., Mayor, Director of Planning, or Director of Strategic Policies, Director of Municipal Development). Keep in mind that IFAM is the institution leading the promotion of municipalities' development in Costa Rica by providing support on technical services, institutional management, planning, and financial management. For the 23 public servants interviewed, notice that the representativeness of the sample is ensured insofar as the respondents work in municipalities located in the seven Costa Rican provinces: nine respondents work in San José (39.13\%), three respondents (13.04\%) work in the provinces of Alajuela, Cartago and Heredia (urban agglomerations); whereas three respondents work in the province of Guanacaste and one interview was obtained for respondents working in the province of Puntarenas and Limón.

Table 2 presents the summary statistics of the budget allocation weights for the seven CCI subindicators. From the descriptive figures in Table 2 we observe limited consensus among experts on the relative importance of the CCI sub-indexes. However, the sub-indicators local administration and (physical and digital) infrastructures emerge as the most relevant variables for most experts, while business environment is the least important sub-indicator for all experts (this sub-index reports the lowest valuation and no expert ranked it on top). Also, all sub-indicators were given a weight by the experts, and no expert proposed equal weights for all sub-indicators. 
We incorporate the experts' valuation of the CCI sub-indicators in the analysis (equation (1)) in the form of numerical weight constraints based on their assessments. Specifically, we added to equation (1) restrictions that capture the sub-indicators' weight bounds, that is, for each CCI subindicators the lower $\left(L_{k}\right)$ and upper $\left(U_{k}\right)$ limits of the 'pie share' constraint are its corresponding minimum and maximum values, respectively (Table 2). Finally, note that all BOD models presented in this study were computed using the GAMS $\odot$ software.

\section{--- Insert Table 2 about here ---}

\section{Results}

\subsection{Efficiency assessment of the local environment of Costa Rican counties}

This section deals with the results of the BOD model (equation (1)). The summary results of the proposed BOD model are presented in Table 3 (by year) and Table 4 (by province).

Overall, the results indicate that the competitive efficiency of Costa Rican counties deteriorated 3.72\% between 2010 and 2016 (Table 3), and that the observed efficiency fall was more pronounced between 2012 and 2014 (Figure 2). Also, findings in Table 4 reveal that the temporal trajectory of the BOD composite indicator is heterogeneous across Costa Rican provinces. Between 2010 and 2016, only two provinces showed an overall positive variation in the efficiency score computed via the BOD model: San José $($ capital $)=4.89 \%$, and Limón $($ Eastern coast $)=31.03 \%$. For the rest of provinces, and during the same period (2010-2016), the negative variation in the BOD-based composite indicator ranges between $-4.13 \%$ (Heredia) and -15.97\% (Puntarenas).

The province of San José (capital region) concentrates most public investments which can explain the reported competitiveness improvement. In the case of the province of Limón, various public specific investments have potentially contributed to improve the region's local competitiveness level, including the improvement of the industrial port facilities with a budgeted investment of nearly one billion US\$, and the improvements in the main highway connecting the region and San José (investment = 456 million US\$) (Costa Rica Ministry of Planning and Economic Policy: https://documentos.mideplan.go.cr/share/s/ka113rCgRbC_BylVRHGgrA).

--- Insert Tables 3 and 4 about here ---

--- Insert Figure 2 about here --- 
The heterogeneity in the configuration of competitive efficiency (pie shares) among Costa Rican counties is in line with the argument that the promotion and development of support policies should take into consideration the specific characteristics of counties' environmental conditions.

For example, for 2016 the competitive efficiency of counties located in the three provinces with the highest $\mathrm{CCI}^{\mathrm{BOD}}$ values (San José, Heredia, and Cartago) is mostly explained by the prioritization of the sub-indicators 'Physical and digital infrastructures' (e.g., paved roads, and access to internet and 4G technology) and 'Innovation' (e.g., rate of exporters in high-tech sectors, university enrolment in science and technology, and rate of education centers with internet connection) (Table 4). In these three provinces (San José, Heredia, and Cartago), investments in highways (San José and Cartago), business centers (San José and Heredia), as well as in free trade zones and a hospital (Cartago) contribute to explain the evolution of competitiveness figures and the observed prioritization of competitive pillars (Costa Rica Ministry of Planning and Economic Policy: https://documentos.mideplan.go.cr/share/s/ka113rCgRbC_BylVRHGgrA).

On contrary, counties located in the two least developed provinces (Puntarenas and Limón) assigned in 2016 around 1/5 of its total competitive score to 'Quality of life' (e.g., governance, policy development) and 'Local administration' (e.g., healthcare, crime, environmental policy); whereas these sub-indicators are the fourth and fifth in the ranking of the top-performing provinces.

Instead of promoting mere quantitative increases in index numbers (in our case, the CCI), these results suggest that a tailor-made policy approach based on the information generated by the proposed BOD model may prove itself more effective in enhancing the quality of counties' competitive environment.

The comparison of rankings based on the CCI values and the results obtained by the proposed BOD model (equation (1)) further reinforce this argument. The county-specific results presented in Table A3 of the Appendix show important discrepancies in the competitive assessment of Costa Rican counties. Notice that the observed differences in both index values and rankings are more evident in counties with a medium and low competitive level, whereas high-competitive counties show similar results based on the CCI and the proposed BOD model. For example, six out of the ten most competitive counties are located in the capital province (San José) and this result is consistent throughout the analyzed composite indicators (CCI and the BOD model). A similar finding is observed for the remaining top competitive counties: three located in the province of Heredia and one located in the province of Cartago (see Table A3 of the Appendix). On contrary, the ranking of poor competitive counties shows a greater variation, which suggests that the competitiveness evaluation of counties may well be obscured by the use of additive index numbers. Notable examples of such cases are the counties of Moravia and Alajuelita in the province of San José, the 
counties of San Ramón and Zarcero in the province of Alajuela; the counties of La Unión and Oreamuno in the province of Cartago, the county of Barva in the province of Heredia, and the county of Nandayure in the province of Guanacaste (see Table A3 in the Appendix).

In this sense, the results of the proposed BOD model represent a more comprehensive efficiency assessment of counties which can offer policy observers richer information if the promotion of specific policies targeting less competitive counties is the desired objective.

From the analysis of the results presented in this section we can conclude that the policy analysis based on informed models (in our case, BOD model) constitutes an ideal scenario for policy makers. In line with our first research question ('how would the analysis of local competitive conditions based on CIs differ when the configuration of its sub-indexes (i.e., endogenous weights) is taken into consideration?'), the proposed analytical tool shows policy-makers how to use additional resources to design optimal policies following endogenous criteria (weights) that may help to maximize the quality of the local environmental conditions.

\subsection{County competitiveness and territorial outcomes}

Following the intuition of our second research question ('does the proposed county-level competitiveness analysis help to unveil competitiveness trajectories that can be used to formulate relevant support policies, linked for instance to business creation and employment figures?'), the analysis presented in section 4.1 would turn sterile if the proposed BOD composite indicator does not permit to infer economically meaningful conclusions because is uncorrelated to territorial outcomes. Thus, the second analytical stage evaluates the connection between the BOD scores and relevant territorial outcomes at the county level related to entrepreneurship (variation in the stock of businesses) and employment (variation in employment).

The proposed regressions_-estimated via fixed-effects estimator-model changes in the stock of firms and changes in employment as a function of the BOD composite indicator (equation (1)). Data obtained from the Costa Rica Institute of Statistics (http://inec.cr) was used to create two county-specific control variables: county size (population) and a set of variables accounting for the configuration of the local industrial fabric (i.e., rate of businesses in extractive, manufacturing, construction, retail, and services). Finally, we included a set of ( $T-1)$ time dummies to rule out unobserved factors that have a homogeneous impact on changes in the dependent variables.

In the regression models, all time-varying variables are lagged one period to correct potential endogeneity problems due to reverse causality. The full fixed-effects model has the following form: $\Delta$ Dependent variable $_{i t}=\beta_{0}+\beta_{1} \mathrm{CCI}^{\text {BOD }}{ }_{i t-1}+\beta_{2}$ Population $_{i t-1}$

$$
+\beta_{3} \text { Local industry configuration }_{i t-1}+\beta_{4} T_{t}+\varepsilon_{i t}
$$


In equation (2) the dependent variables are the variation rate in the stock of businesses and the variation rate in employment, $\boldsymbol{\beta}$ is the vector of coefficients estimated for the independent variables, while the error $\left(\varepsilon_{i t}=\eta_{i}+\nu_{i t}\right)$ includes an unobserved county-specific time invariant effect $\left(\eta_{i}\right)$ that accounts for unobservable heterogeneity and a stochastic disturbance $\left(\nu_{i t}\right)$ that varies crosscounties and cross time. Descriptive statistics and bivariate correlations for the study variables are presented in Table 5, while Table 6 offers the empirical results.

\section{--- Insert Tables 5 and 6 about here ---}

Regression results in Table 6 reveal that the variation rate in both dependent variables (stock of businesses and employment) is positively associated with the BOD composite indicator, that is, improvements in the quality of the local ecosystem are conducive to superior territorial performance. More concretely, in the case of the variation rate in the stock of businesses the coefficient for the variable linked to the BOD composite indicator $\left(C C I^{B O D}\right)$ in model 2 indicates that a 10-point improvement in the $C C I^{B O D}$ increases the stock of businesses by 0.54 percentage points. Similarly, an increase of 10 points in the $C C I^{B O D}$ would produce a raise of 0.71 percentage points in the county's employment level.

Finally notice that, for comparison purposes, we also estimated equation (2) using the CCI values. Results presented in Table A4 of the Appendix confirm the greater explanatory power of the proposed index number (BOD variable), relative to the CCI values.

The objective of this second stage analysis was to show that the information power of the proposed BOD composite indicator may contribute to unveil how the quality of the (multidimensional) local environment can produce specific impacts on relevant territorial outcomes with societal implications. The core findings of this analysis validate the interpretations presented in section 4.1: the study of local ecosystems should go beyond quantitative metrics and include into the analysis information that helps to produce more complete and informative composite indicators.

\subsection{Robustness checks}

This section presents the results of the robustness checks evaluating the suitability of the proposed BOD model (equation (1)) compared to three alterative specifications. The first baseline model assumes 'full flexibility' in the sub-indicators weights (BOD-1) by removing the 'pie share' 
restriction from equation (1). The second alternative model imposes common weight bounds to the CCI sub-indicators (BOD-2: $0 \leq w_{k} \leq 0.1450$ ). The third BOD model uses factor analysis (principal component analysis) to identify the importance of each of the seven sub-indicators of the CCI (BOD-3). In this case, and based on the results of the factor model, the weights assigned to each sub-indicator of the CCI are the following: Local economy $(\mathrm{Y} 1)=0.0633$; Local administration $(\mathrm{Y} 2)=0.0292$; Physical and digital infrastructures $(\mathrm{Y} 3)=0.2876$; Business environment $(\mathrm{Y} 4)=$ 0.1494; Human capital $(\mathrm{Y} 5)=0.1439$; Innovation $(\mathrm{Y} 6)=0.2724$; and Quality of life $(\mathrm{Y} 7)=0.0543$.

The summary results of the different BOD models are presented in Table 7. From the findings in Table 7 and Figure A1 in the Appendix we note that, compared to the BOD model estimated via equation (1), the composite indicator (CI) efficiency significantly improves in the 'full flexibility' BOD model (in every period the CI efficiency is higher than 0.70). Keep in mind that the 'full flexibility' model considers the possibility that counties ignore those pillars on which they perform relatively poor (and assign greater weights to high-performing sub-indicators), which explains the reported efficiency discrepancies. The shift in the distribution of efficiency estimates (BOD model vs. BOD-1) is statistically significant (Figure A1) (Kolmogorov-Smirnov test for equality of distribution functions $=0.5150, p$-value $<0.000)$. A similar result has been reported in prior work based on BOD models (e.g., Cherchye et al., 2008; Karagiannis and Karagiannis, 2019).

\section{--- Insert Table 7 about here ---}

The CI scores computed via models BOD-2 (common weight bounds) and BOD-3 (weights estimated via factor analysis) follow a temporal trajectory that is comparable to that observed for the main BOD model (equation (1)) (Table 7). Also, the results from models BOD-2 and BOD-3 are comparatively lower than those reported for the main BOD model (equation (1)) (see Figures A2 and A3 in the Appendix): main BOD model vs. model BOD-2: Kolmogorov-Smirnov test for equality of distribution functions $=0.4215, p$-value $<0.000$; and main BOD model vs. model BOD3: Kolmogorov-Smirnov test for equality of distribution functions $=0.2875, p$-value $<0.000$.

The objective of the supplementary analyses presented in this section was to show that the estimation strategy adopted to generate the main findings of this study (sections 4.1 and 4.2) is robust to alternative specifications and weighting approaches. From the results presented in this section it is evident that the additional constraints on the pie shares resulting from experts' information allowed for a better assessment of counties' competitive efficiency via the proposed BOD composite indicator. The core findings of this test corroborate that the BOD model (equation (1)) is a valid and more realistic approach to evaluate the competitive performance of territories and 
generate valuable information on policy priorities that can be used to produce quality improvements in the environmental conditions included in the county competitiveness index (CCI).

\section{Concluding remarks, policy implications and future research lines}

\subsection{Concluding remarks}

This study has produced evidence on the importance of computing composite indicators using endogenous weights for optimal policy design that informs policy makers and other stakeholders about territories' competitive level. Additionally, our findings suggest that the proposed composite indicator analysis based on the 'benefit of the doubt' approach with endogenous weights is a potentially decisive source of information for optimal policy diagnosis in a developing setting.

We argue that composite indicator analyses should go beyond canonical rankings and homogeneous prescription, and promote the generation of reliable information that can be used to equip policy makers with the means for developing tailor-made support policies. This is especially relevant in developing settings where contrasted information may offer policy makers more directed guidelines to activate specific strategies that also optimize the allocation of (scarce) resources.

Overall, the results are consistent with the view that the proposed composite indicator analysis based on the 'benefit of the doubt' model provides valuable insights on what dimensions of the focal composite indicator-in our case, the CCI—should be prioritized if the enhancement of local competitive conditions is the desired goal. Instead of quantity variations and basic ranking, we show how quality improvements in territorial outcomes - that we link to entrepreneurship (stock of businesses) and employment—can be realized by analyzing composite indicators using the proposed 'benefit of the doubt' approach following objective, more informed criteria based on the ex-ante policy priorities (endogenous weights) identified by experts.

By evaluating the connection between competitive efficiency (BOD model) and economic performance (variation in the stock of businesses and changes in employment), our analysis also contributes to understand how public administrations can adopt specific policies to potentially direct improvements in their territories—-measured via the proposed composite indicator-with the objective to enhance relevant territorial outcomes with a long-term perspective.

\subsection{Policy implications}

What policy lessons can be extracted from the proposed analysis of composite indicators designed to evaluate the competitive level of Costa Rican counties? In an increasingly complex economic environment, territories face competing demands, and policy makers struggle between the design of coordinated support policies and the selection of accurate measures to assess the degree of 
achievement of the set goals. The policy implications discussed in this section emerge from the results of the study, and are strictly connected to our research questions.

Valuable information based on index numbers to analyze territories' competitive level.-Our analysis shows how a 'benefit of the doubt' model with endogenous weights based on experts' opinion can be instrumental for the identification of policy priorities at local level, as well as for the accurate evaluation of counties' competitiveness level. In contexts of insufficient information about the relative importance of the variables that shape a focal phenomenon, as in the case of territories' competitive level, the 'benefit of the doubt' approach constitutes a valuable method to evaluate composite indicators and reduce the uncertainty that often questions the validity of composite indicators (Cherchye et al., 2008; Sahoo et al., 2017). Although there is no perfect recipe to build a universally accepted composite indicator, the detailed nature of the analyzed data and the objective of the studied index number should provide enough feedback into the generation of economically meaningful CIs. In the specific case of the CCI index, the computation of endogenous weights based on experts' opinion can prove itself effective to identify policy priorities that can become the target of a more informed competitiveness-enhancing policy. This critical aspect is connected to our first research question ('how would the analysis of local competitive conditions based on CIs differ when the configuration of its sub-indexes (i.e., endogenous weights) is taken into consideration?').

Isomorphic policy-making is not an optimal competitiveness-enhancing strategy.-In a closely related manner, an important implication of our analysis is that optimal policy-making should not be based on institutional isomorphism, that is, a convergence strategy based on the replication of what other, often more developed peers, do. In connection to our second research question ('does the proposed county-level competitiveness analysis help to unveil competitiveness trajectories that can be used to formulate relevant support policies, linked for instance to business creation and employment figures?'), we argue that a newly re-defined policy that emphasizes selective improvements in the local ecosystem constitutes an alternative pattern of change in developing economies. Even though a quantity improvement in the CCI index can be perceived as good news, the results of the regression analysis indicate that a more rationalized and diagnostic assessment of the sources of competitiveness among Costa Rican counties would produce even more effective economic outcomes. That is, optimal support policy relies less on the mere deployment of more resources and instead involves direct encouragement to the development of specific policies that target those aspects of the local ecosystem that should be improved, according to the analysis based on the BOD model.

Additionally, by using the objective BOD approach to compute endogenous county-specific weights, we show how the proposed analysis of counties’ competitiveness (BOD model) contributes 
to minimize policy-makers’ 'discretionary decision-making' by identifying specific priorities-i.e., relevant indicators or CCI sub-indicators- that can be targeted to optimize resource allocation policies, thus generating quality improvements of the competitive level of Costa Rican counties.

\subsection{Future research lines}

As with any study, the findings presented in this study are open to future verification. In this sense, it would be valuable to extend the proposed analysis in various directions. First, and similar to other studies dealing with composite indicator analyses (e.g., Cherchye et al., 2008; Karagiannis and Karagiannis, 2019), the data do not permit the direct analysis of the decision-making process underlying the generation and implementation of support policies. Further work can address this issue by exploring the economic- and policy-led antecedents of competitiveness-enhancing policies. Second, the composite indicator analyzed in this study (i.e., CCI) equalizes the seven sub-indicator averages to compare the improvement effect over these sub-indicators; however, this assumption may not accurately reflect the economic cost of improving the CCI index because these costs may vary significantly across sub-indicators (Acs et al., 2014; Lafuente et al., 2019). As many other indicators (e.g., Mizobuchi, 2014; Sahoo et al., 2017), the CCI does not consider the differences in the economic efforts necessary to improve counties' competitiveness. Of course, the cost of improving a focal sub-indicator in a large county—e.g., the capital of a province—can be much higher than that needed in smaller or less developed counties. An interesting future research line deals with the quantification of the economic investments associated with competitiveness enhancing policies. Finally, the analysis presented in the study is based on discrete estimations which partially capture counties' competitiveness efficiency. The longitudinal study of productivity changes is relevant and future work should evaluate the effects of specific policies on counties' competitiveness using longitudinal BOD models based on TFP measures.

Acknowledgements: The authors are indebted to members of the Observatory of Development and the School of Economics of the University of Costa Rica (in particular to Bernardo Mayorga Salas and the Director of the CCI, Prof. Annabelle Ulate Quirós) for facilitating the data used in this study. For their ideas and insights we are grateful to the two anonymous referees and participants at the 7th International Workshop on Efficiency in Education, Health and other Public Services (Universitat Internacional de Catalunya, September 2019). The authors are also thankful to Laurens Cherchye (KU Leuven) and Nicky Rogge (KU Leuven) for their support with the GAMS baseline code used in this study to compute the BOD models. This research received financial support from the Spanish Ministry of Economy, Industry and Competitiveness (grant: ECO2017-86305-C4-2-R). 


\section{References}

Acs, Z.J., Autio, E., Szerb, L. (2014). National systems of entrepreneurship: Measurement issues and policy implications. Research Policy, 43(3), 476-494.

Alonso, S., Leiva, J. C. (2019). Business competitiveness in Costa Rica: a multidimensional approach. TEC Empresarial, 13(3), 28-41.

Araya, M. (2019). Efficiency assessment of Costa Rica’s counties: A non-parametric analysis of the county competitiveness index. TEC Empresarial, 13(3), 78-92.

Balaguer-Coll, M.T., Prior, D., Tortosa-Ausina, E. (2007). On the determinants of local government performance: A two-stage nonparametric approach. European Economic Review, 51(2), 425451.

Calcagnini, G., Perugini, F. (2018). Social capital and well-being in the Italian provinces. SocioEconomic Planning Sciences, in press. doi: https://doi.org/10.1016/j.seps.2018.11.005

Charnes, A., Cooper, W.W., Rhodes, E. (1978). Measuring the efficiency of decision making units. European Journal of Operational Research, 2(6), 429-444.

Cherchye, L., Moesen, W., Rogge, N., Van Puyenbroeck, T. (2007). An introduction to 'benefit of the doubt'composite indicators. Social Indicators Research, 82 (1), 111-145.

Cherchye, L., Moesen, W., Rogge, N., Van Puyenbroeck, T., Saisana, M., Saltelli, A., Liska, R., Tarantola, S. (2008). Creating composite indicators with DEA and robustness analysis: the case of the Technology Achievement Index. Journal of the Operational Research Society, 59(2), 239251.

Cooper, W.W., Seiford, L.M., Zhu, J. (2011). Handbook on data envelopment analysis (2nd edition). Springer, New York.

Despotis, D.K. (2005). A reassessment of the human development index via data envelopment analysis. Journal of the Operational Research Society, 56, 969-980.

European Commission (2017). The Quality of Public Administration: A “Toolbox” for Practitioners. Publications Office of the European Union, Luxembourg.

Freudenberg, M. (2003). Composite indicators of country performance: A critical assessment, STI Working Paper 2003/16, OECD, Paris.

Friedman, M., Schwartz, A.J. (1991). Alternative approaches to analyzing economic data. American Economic Review, 81 (1), 39-49.

Glaeser, E., Kallal, H., Scheinkman, J., Shleifer, A. (1992). Growth in cities. Journal of Political Economy, 100(6), 1126-1152. 
Karagiannis, R., Karagiannis, G. (2018). Intra-and inter-group composite indicators using the BoD model. Socio-Economic Planning Sciences, 61, 44-51.

Karagiannis, R., Karagiannis, G. (2019). Constructing composite indicators with Shannon entropy: The case of Human Development Index. Socio-Economic Planning Sciences, in press, doi: https://doi.org/10.1016/j.seps.2019.03.007

Karagiannis, G., Lovell, C.A.K. (2016). Productivity measurement in radial DEA models with a single constant input. European Journal of Operational Research, 251 (1), 323-328.

Lafuente, E., Acs, Z.J., Sanders, M., Szerb, L. (2019). The global technology frontier: productivity growth and the relevance of Kirznerian and Schumpeterian entrepreneurship. Small Business Economics, in press, doi: https://doi.org/10.1007/s11187-019-00140-1

Lafuente, E., Vaillant, Y., Leiva, J.C. (2018). Sustainable and Traditional Product Innovation without Scale and Experience, but only for KIBS! Sustainability, 10(4), 1169.

Leontief, W. (1971). Theoretical assumptions and nonobserved facts. American Economic Review, $61(1), 1-7$.

Lin, M.I., Lee, Y.D., Ho, T.N. (2011). Applying integrated DEA/AHP to evaluate the economic performance of local governments in China. European Journal of Operational Research, 209(2), 129-140.

Lovell, C.A.K., Pastor, J.T. (1999). Radial DEA models without inputs or without outputs. European Journal of Operational Research, 188 (1), 46-51.

Melyn, W., Moesen, W. (1991). Towards a synthetic indicator of macroeconomic performance: unequal weighting when limited information is available. Public Economic Research Paper 17, CES, KU Leuven.

Mizobuchi, H. (2014). Measuring world better life frontier: A composite indicator for OECD better life index. Social Indicators Research, 118, 987-1007.

Nunnally, J.C., Bernstein, I.H. (1994). Psychometric Theory. McGraw-Hill, New York.

OECD (2008). Handbook on constructing composite indicators: methodology and user guide. OECD Publications, Paris.

OECD (2015). OECD Establishes Roadmap for Membership with Costa Rica. OECD Newsroom, 15 July 2015. Available at: https://www.oecd.org/newsroom/oecd-establishes-roadmap-formembership-with-costa-rica.htm (accessed on 9 February2020).

OECD (2016). OECD Economic Surveys: Costa Rica 2016—Economic Assessment; OECD Publishing: Paris, France.

OECD (2017). Government at a Glance 2017. OECD Publishing, Paris, doi: http://dx.doi.org/10.1787/gov_glance-2017-en 
OECD (2018). OECD Economic Surveys: Costa Rica 2018, Economic Assessment, OECD Publishing: Paris (p.32-38).

Sahoo, B.K., Singh, R., Mishra, B., Sankaran, K. (2017). Research productivity in management schools of India during 1968-2015: A directional benefit-of-doubt model analysis. Omega, 66, 118-139.

Ulate, A., Madrigal, G., Ortega, R., Jiménez, E. (2012). Índice de competitividad cantonal, 20062011 (2nd ed.). Disponible en: http://www.icc.odd.ucr.ac.cr/docs/ICC-OdD-2012.pdf.

Ulate, A., Mayorga, B., Alfaro, J. (2016). Índice de Competitividad Cantonal. Disponible en: https://www.ucr.ac.cr/medios/documentos/2017/icc-odd-2006-2016.pdf. 


\section{List of Figures}

Figure 1. County competitiveness index (CCI) across Costa Rican counties (left: 2010; right: 2016)
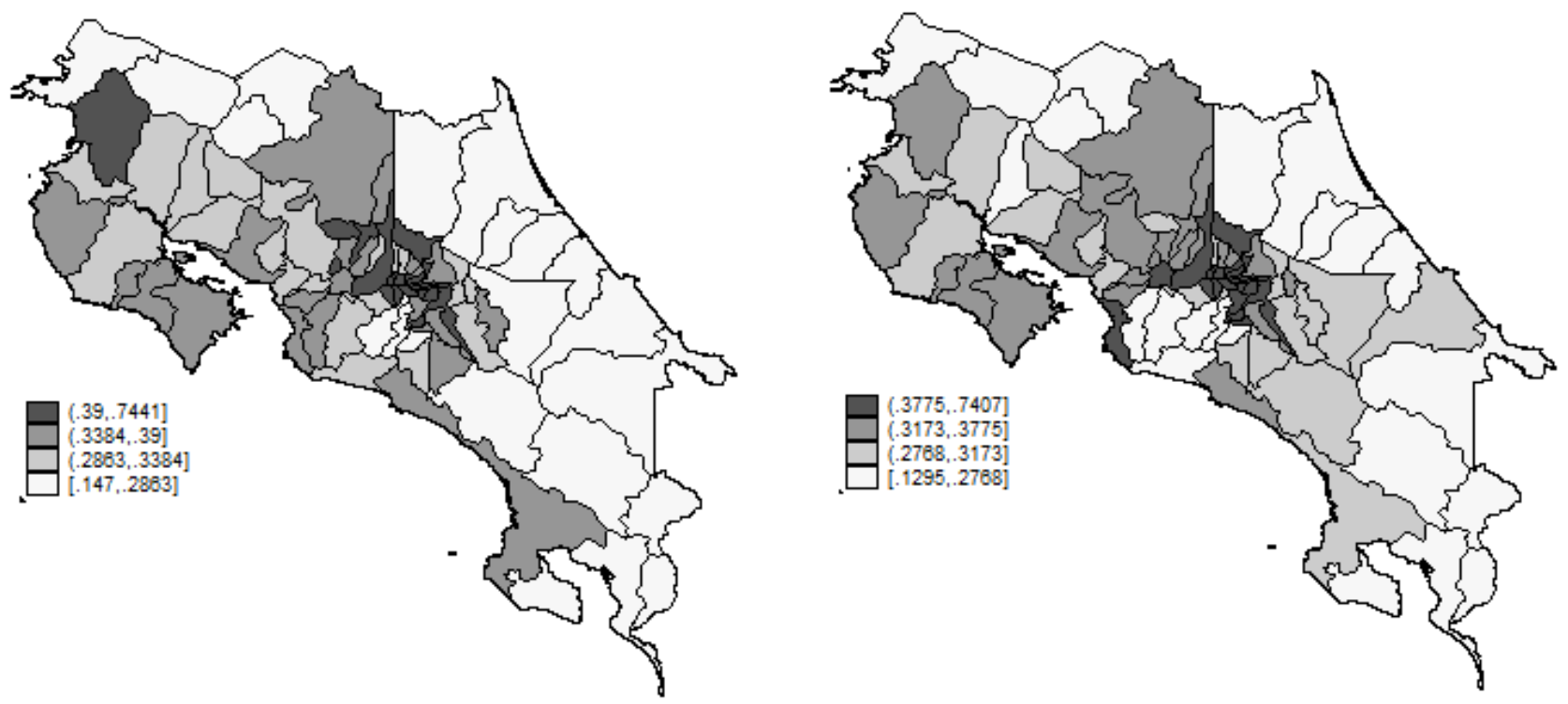

Source: Authors' elaboration based on the study data (CCI).

Figure 2. County performance (CCI) and efficiency assessment of the CCI score (BOD model)

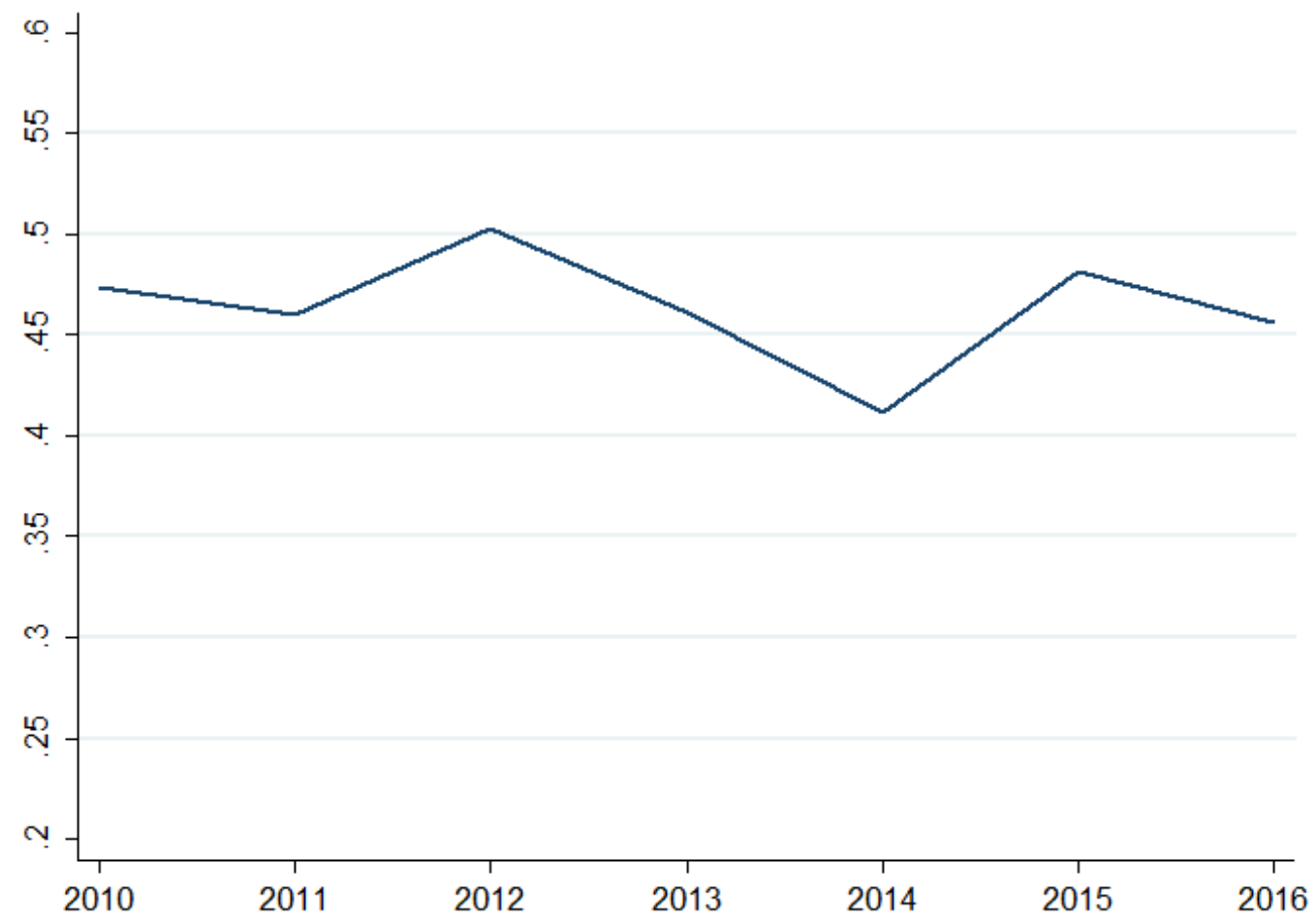

Source: Authors' elaboration based on the study results (equation (1)). 


\section{List of Tables}

Table 1. Descriptive statistics: County competitiveness index (CCI) and its sub-indicators

\begin{tabular}{|l|c|l|c|l|c|c|c|c|}
\hline & $\begin{array}{l}\text { County } \\
\text { competitiveness } \\
\text { index (CCI) }\end{array}$ & $\begin{array}{l}\text { Local } \\
\text { economy }\end{array}$ & $\begin{array}{l}\text { Local } \\
\text { administration }\end{array}$ & $\begin{array}{l}\text { Physical and } \\
\text { digital } \\
\text { infrastructures }\end{array}$ & $\begin{array}{l}\text { Business } \\
\text { environment }\end{array}$ & $\begin{array}{l}\text { Human } \\
\text { capital }\end{array}$ & Innovation & Quality of life \\
\hline \multirow{2}{*}{2010} & $\begin{array}{c}0.3471 \\
(0.1164)\end{array}$ & $\begin{array}{c}0.2438 \\
(0.1386)\end{array}$ & $\begin{array}{c}0.4115 \\
(0.2240)\end{array}$ & $\begin{array}{c}0.4534 \\
(0.2171)\end{array}$ & $\begin{array}{c}0.2782 \\
(0.2021)\end{array}$ & $\begin{array}{c}0.3823 \\
(0.2104)\end{array}$ & $\begin{array}{c}0.3425 \\
(0.2193)\end{array}$ & $\begin{array}{c}0.3179 \\
(0.2057)\end{array}$ \\
\hline \multirow{2}{*}{2011} & 0.3432 & 0.2478 & 0.2866 & 0.4679 & 0.2797 & 0.4040 & 0.3873 & 0.3291 \\
& $(0.1190)$ & $(0.1329)$ & $(0.1788)$ & $(0.2183)$ & $(0.1918)$ & $(0.2014)$ & $(0.2277)$ & $(0.2035)$ \\
\hline \multirow{2}{*}{2012} & 0.3442 & 0.3019 & 0.2862 & 0.4710 & 0.3124 & 0.3972 & 0.3916 & 0.2491 \\
& $(0.1133)$ & $(0.1371)$ & $(0.1939)$ & $(0.2111)$ & $(0.1833)$ & $(0.1673)$ & $(0.2206)$ & $(0.1896)$ \\
\hline \multirow{2}{*}{2013} & 0.3344 & 0.1664 & 0.3664 & 0.4786 & 0.3060 & 0.4084 & 0.3822 & 0.2330 \\
& $(0.1217)$ & $(0.1454)$ & $(0.2348)$ & $(0.2084)$ & $(0.1865)$ & $(0.1935)$ & $(0.2335)$ & $(0.1691)$ \\
\hline \multirow{2}{*}{2014} & 0.3409 & 0.1812 & 0.2934 & 0.4772 & 0.2850 & 0.4773 & 0.4204 & 0.2518 \\
& $(0.1336)$ & $(0.1891)$ & $(0.1935)$ & $(0.2766)$ & $(0.1719)$ & $(0.1863)$ & $(0.2090)$ & $(0.1914)$ \\
\hline \multirow{2}{*}{2015} & 0.3368 & 0.2026 & 0.2918 & 0.4612 & 0.2720 & 0.4560 & 0.4033 & 0.2707 \\
& $(0.1220)$ & $(0.1643)$ & $(0.1655)$ & $(0.2560)$ & $(0.1771)$ & $(0.1753)$ & $(0.2219)$ & $(0.1732)$ \\
\hline \multirow{2}{*}{2016} & 0.3369 & 0.3210 & 0.2614 & 0.4241 & 0.2643 & 0.4317 & 0.3701 & 0.2857 \\
& $(0.1221)$ & $(0.1394)$ & $(0.1766)$ & $(0.2393)$ & $(0.1865)$ & $(0.1969)$ & $(0.2142)$ & $(0.1884)$ \\
\hline \multirow{2}{*}{ Total } & 0.3405 & 0.2378 & 0.3139 & 0.4619 & 0.2854 & 0.4224 & 0.3854 & 0.2768 \\
& $(0.1207)$ & $(0.1595)$ & $(0.2020)$ & $(0.2331)$ & $(0.1855)$ & $(0.1923)$ & $(0.2210)$ & $(0.1911)$ \\
\hline
\end{tabular}

Sample size: 81 counties 
Table 2. Summary statistics on the weight assigned to the CCI sub-indexes by the panel of experts

\begin{tabular}{|l|c|c|c|c|c|c|}
\hline Sub-index (pillar) & Average & Median & Std. dev. & Min. & Max. & $\begin{array}{c}\text { Ranking* } \\
\text { (top / bottom) }\end{array}$ \\
\hline Local economy & 0.1227 & 0.1000 & 0.0545 & 0.05 & 0.25 & $6 / 6$ \\
\hline Local administration & 0.1773 & 0.1500 & 0.0840 & 0.07 & 0.40 & $9 / 3$ \\
\hline $\begin{array}{l}\text { Physical and digital } \\
\text { infrastructures }\end{array}$ & 0.1862 & 0.1750 & 0.0842 & 0.07 & 0.50 & $8 / 1$ \\
\hline Business environment & 0.1154 & 0.1000 & 0.0400 & 0.05 & 0.20 & $0 / 4$ \\
\hline Human capital & 0.1312 & 0.1400 & 0.0399 & 0.05 & 0.20 & $2 / 3$ \\
\hline Innovative capacities & 0.1208 & 0.1000 & 0.0627 & 0.05 & 0.30 & $6 / 7$ \\
\hline Quality of life & 0.1465 & 0.1200 & 0.0813 & 0.05 & 0.30 & $5 / 6$ \\
\hline
\end{tabular}

Total number of observations $=26$ experts. Note $*=$ Figures indicate the number of times the focal sub-index was ranked on top and at the bottom by the group of experts. The vertical sum exceeds the total number of experts (26) due to tied preferences.

Table 3. Empirical results (BOD model): Competitive efficiency $\left(C C I_{i}^{B O D}\right.$ ) by year

\begin{tabular}{|l|c|c|c|c|c|}
\hline & Mean & Median & Std. dev. & Q1 & Q3 \\
\hline 2010 & 0.4741 & 0.4991 & 0.2224 & 0.3741 & 0.5965 \\
\hline 2011 & 0.4604 & 0.4678 & 0.2022 & 0.3375 & 0.5716 \\
\hline 2012 & 0.5029 & 0.5307 & 0.2116 & 0.3890 & 0.6253 \\
\hline 2013 & 0.4609 & 0.4966 & 0.2378 & 0.3389 & 0.5738 \\
\hline 2014 & 0.4118 & 0.4059 & 0.2138 & 0.2779 & 0.5407 \\
\hline 2015 & 0.4818 & 0.4944 & 0.2150 & 0.3619 & 0.5933 \\
\hline 2016 & 0.4564 & 0.4658 & 0.2207 & 0.3367 & 0.5630 \\
\hline Total & $\mathbf{0 . 4 6 4 0}$ & $\mathbf{0 . 4 7 7 7}$ & $\mathbf{0 . 2 1 8 3}$ & $\mathbf{0 . 3 4 0 5}$ & $\mathbf{0 . 5 8 7 7}$ \\
\hline
\end{tabular}

Sample size: 81 counties 
Table 4. Empirical results (BOD model): Competitive efficiency $\left(C C I_{i}^{B O D}\right.$ ) by province

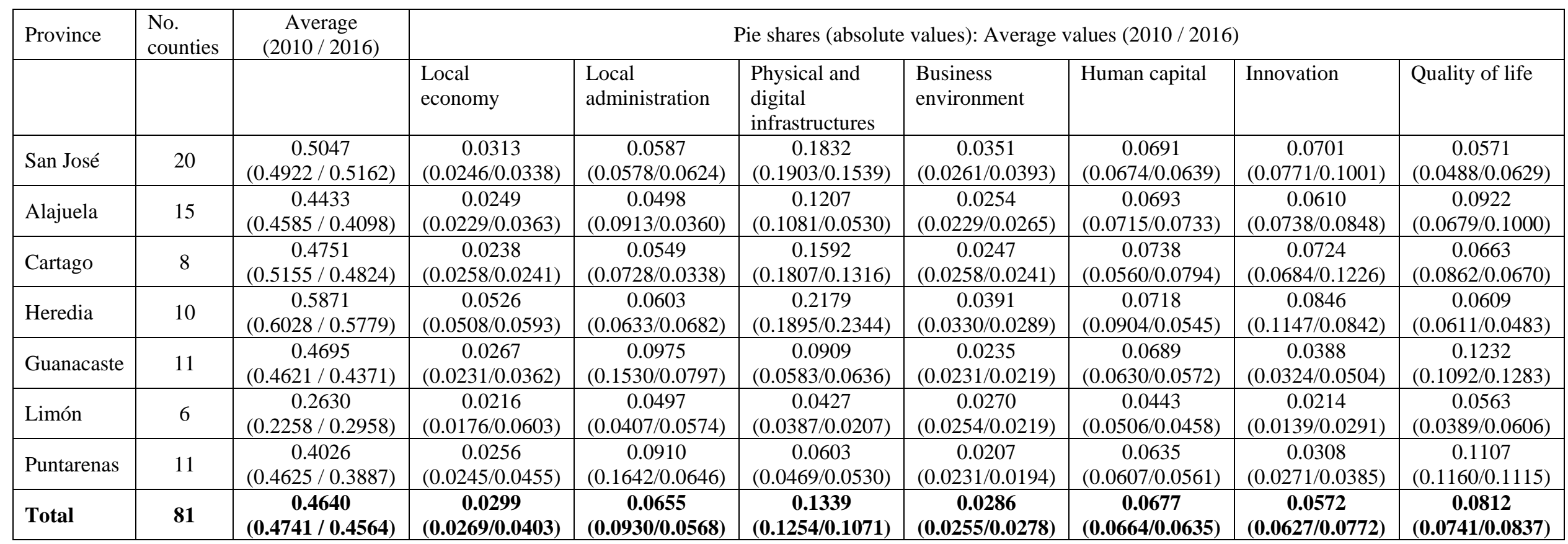

The 81 Costa Rican counties are grouped in seven provinces. Standard deviation is presented in parentheses. The table presents average figures for the full period (2010-2016) and mean values for 2010 and 2016 are in parentheses (i.e., figures in parentheses should be read as “average for 2010 / average for 2016 ”). 
Table 5. Regression analysis: Descriptive statistics and bivariate correlations (2011-2016)

\begin{tabular}{|c|c|c|c|c|c|c|c|c|c|c|c|}
\hline & & Mean & Std. dev. & 1 & 2 & 3 & 4 & 5 & 6 & 7 & 8 \\
\hline 1 & $\begin{array}{l}\text { Variation rate in } \\
\text { workers }\end{array}$ & 0.0303 & 0.0531 & 1.0000 & & & & & & & \\
\hline 2 & $\begin{array}{l}\text { Variation rate in } \\
\text { stock of businesses }\end{array}$ & 0.0253 & 0.0606 & $0.3535 * * *$ & 1.0000 & & & & & & \\
\hline 3 & $\begin{array}{l}C C I_{i}^{B O D} \\
\text { (BOD model) }\end{array}$ & 0.4640 & 0.2183 & 0.0694 & $0.1335 * * *$ & 1.0000 & & & & & \\
\hline 4 & $\begin{array}{l}\text { Population } \\
\text { (thousand) }\end{array}$ & 58.1788 & 57.3798 & 0.0488 & 0.0502 & $0.2273 * * *$ & 1.0000 & & & & \\
\hline 5 & $\begin{array}{l}\text { Proportion of } \\
\text { manufacturers }\end{array}$ & 0.0609 & 0.0229 & 0.0250 & $0.1206 * * *$ & $0.1238 * * *$ & $0.1364 * * *$ & 1.0000 & & & \\
\hline 6 & $\begin{array}{l}\text { Proportion of } \\
\text { extractive firms }\end{array}$ & 0.1710 & 0.1374 & 0.0002 & $-0.0980 * *$ & $-0.4740 * * *$ & $-0.5571^{* * *}$ & $-0.3052 * * *$ & 1.0000 & & \\
\hline 7 & $\begin{array}{l}\text { Proportion of } \\
\text { construction firms }\end{array}$ & 0.0702 & 0.0280 & $0.0767 *$ & $0.1851^{* * *}$ & $0.1837 * * *$ & $0.1943^{* * *}$ & $0.2336 * * *$ & $-0.4283^{* * *}$ & 1.0000 & \\
\hline 8 & $\begin{array}{l}\text { Proportion of } \\
\text { retailers }\end{array}$ & 0.2479 & 0.0576 & $-0.1433 * * *$ & -0.0600 & $-0.0943 * *$ & $0.3979 * * *$ & $0.2609 * * *$ & $-0.4206^{* * *}$ & -0.0373 & 1.0000 \\
\hline 9 & $\begin{array}{l}\text { Proportion of } \\
\text { service firms }\end{array}$ & 0.4500 & 0.1118 & 0.0497 & $0.0816^{*}$ & $0.5598 * * *$ & $0.4032 * * *$ & -0.0222 & $-0.8426 * * *$ & $0.2475^{* * *}$ & -0.0423 \\
\hline
\end{tabular}

Sample size: 486 observations (81 counties between 2011 and 2016). *, **, *** indicates that the bivariate correlation is significant at the 10\%, 5\% and 1\%, respectively. 
Table 6. Fixed-effects regression results: Competitive efficiency and local outcomes

\begin{tabular}{|c|c|c|c|c|}
\hline & \multicolumn{2}{|c|}{$\begin{array}{l}\text { Variation rate in the stock of } \\
\text { businesses (business flow rate) }\end{array}$} & \multicolumn{2}{|c|}{$\begin{array}{l}\text { Variation rate in employment } \\
\text { (workers) }\end{array}$} \\
\hline Independent variables & $(1)$ & $(2)$ & $(1)$ & $(2)$ \\
\hline$C C I_{i}^{B O D} t-1$ & $\begin{array}{l}0.0667 * * \\
(2.01)\end{array}$ & $\begin{array}{c}0.0543^{*} \\
(1.82)\end{array}$ & $\begin{array}{c}0.0897 * * * \\
(3.03)\end{array}$ & $\begin{array}{l}0.0712^{* *} \\
(2.36)\end{array}$ \\
\hline Population (ln) $t-1$ & & $\begin{array}{l}0.2710 \\
(0.88) \\
\end{array}$ & & $\begin{array}{l}0.0950 \\
(0.34) \\
\end{array}$ \\
\hline $\begin{array}{l}\text { Proportion of extractive } \\
\text { businesses } t-1\end{array}$ & & $\begin{array}{c}-0.5447 \\
(1.22)\end{array}$ & & $\begin{array}{c}-0.4666 \\
(1.17)\end{array}$ \\
\hline $\begin{array}{l}\text { Proportion of construction } \\
\text { businesses } t-1\end{array}$ & & $\begin{array}{l}-1.4991^{* *} \\
(1.98)\end{array}$ & & $\begin{array}{c}-1.3920 * * * \\
(2.67)\end{array}$ \\
\hline $\begin{array}{l}\text { Proportion of retailing } \\
\text { businesses } t-1\end{array}$ & & $\begin{array}{c}-0.7928 * \\
(1.74)\end{array}$ & & $\begin{array}{c}-0.7762^{*} \\
(1.91)\end{array}$ \\
\hline $\begin{array}{l}\text { Proportion of businesses in } \\
\text { service sectors } t-1\end{array}$ & & $\begin{array}{c}-1.0051^{* *} \\
(2.20)\end{array}$ & & $\begin{array}{c}-0.5093 \\
(1.25)\end{array}$ \\
\hline Time dummies & Yes & Yes & Yes & Yes \\
\hline Intercept & $\begin{array}{c}0.0262^{*} \\
(1.69)\end{array}$ & $\begin{array}{c}-2.0186 \\
(0.61)\end{array}$ & $\begin{array}{c}0.0064 \\
(0.44)\end{array}$ & $\begin{array}{c}-0.3908 \\
(0.13)\end{array}$ \\
\hline F-test & $4.78 * * *$ & $4.45^{* * *}$ & $6.24 * * *$ & $5.08 * * *$ \\
\hline R2 (within) & 0.0857 & 0.1230 & 0.0858 & 0.1132 \\
\hline Average VIF & 1.56 & 8.61 & 1.56 & 8.61 \\
\hline Observations (counties) & $486(81)$ & $486(81)$ & $486(81)$ & $486(81)$ \\
\hline
\end{tabular}

The time-varying independent variables are lagged one period to avoid potential endogeneity problems. All models include a set of $(t-1)$ time dummies. The proportion of manufacturing firms is the omitted industry category. Values in parentheses are absolute $t$-values, based on robust standard errors adjusted by heteroskedasticity. ${ }^{*}, * *, * *$ indicate significance at the $10 \%, 5 \%$ and $1 \%$, respectively. 
Table 7. Robustness checks: Results of different 'benefit of the doubt' (BOD) models

\begin{tabular}{|c|c|c|c|c|c|}
\hline & $\begin{array}{l}\text { BOD model } \\
\text { (equation (1)) }\end{array}$ & Model BOD-1 & Model BOD-2 & Model BOD-3 & $\begin{array}{l}\text { No. } \\
\text { counties }\end{array}$ \\
\hline 2010 & $\begin{array}{c}0.4741 \\
(0.2224)\end{array}$ & $\begin{array}{c}0.7425 \\
(0.1767)\end{array}$ & $\begin{array}{c}0.3189 \\
(0.1728)\end{array}$ & $\begin{array}{c}0.3471 \\
(0.2199)\end{array}$ & 81 \\
\hline 2011 & $\begin{array}{c}0.4604 \\
(0.2022) \\
\end{array}$ & $\begin{array}{c}0.7113 \\
(0.1774) \\
\end{array}$ & $\begin{array}{c}0.3158 \\
(0.1589) \\
\end{array}$ & $\begin{array}{c}0.3678 \\
(0.2026) \\
\end{array}$ & 81 \\
\hline 2012 & $\begin{array}{c}0.5029 \\
(0.2116) \\
\end{array}$ & $\begin{array}{c}0.7041 \\
(0.1859) \\
\end{array}$ & $\begin{array}{c}0.3571 \\
(0.1781) \\
\end{array}$ & $\begin{array}{c}0.3996 \\
(0.2124) \\
\end{array}$ & 81 \\
\hline 2013 & $\begin{array}{c}0.4609 \\
(0.2378)\end{array}$ & $\begin{array}{c}0.7121 \\
(0.1862)\end{array}$ & $\begin{array}{c}0.2981 \\
(0.1869)\end{array}$ & $\begin{array}{c}0.3507 \\
(0.2235)\end{array}$ & 81 \\
\hline 2014 & $\begin{array}{c}0.4118 \\
(0.2138) \\
\end{array}$ & $\begin{array}{c}0.7063 \\
(0.1935) \\
\end{array}$ & $\begin{array}{c}0.2860 \\
(0.1897) \\
\end{array}$ & $\begin{array}{c}0.3437 \\
(0.2140) \\
\end{array}$ & 81 \\
\hline 2015 & $\begin{array}{c}0.4818 \\
(0.2150)\end{array}$ & $\begin{array}{c}0.7110 \\
(0.1922)\end{array}$ & $\begin{array}{c}0.3431 \\
(0.1890)\end{array}$ & $\begin{array}{c}0.3782 \\
(0.2197)\end{array}$ & 81 \\
\hline 2016 & $\begin{array}{c}0.4564 \\
(0.2207) \\
\end{array}$ & $\begin{array}{c}0.7013 \\
(0.1920) \\
\end{array}$ & $\begin{array}{c}0.3362 \\
(0.1983) \\
\end{array}$ & $\begin{array}{c}0.3709 \\
(0.2320) \\
\end{array}$ & 81 \\
\hline Total & $\begin{array}{c}0.4640 \\
(0.2183) \\
\end{array}$ & $\begin{array}{c}0.7127 \\
(0.1858) \\
\end{array}$ & $\begin{array}{c}0.3222 \\
(0.1829) \\
\end{array}$ & $\begin{array}{c}0.3654 \\
(0.2176) \\
\end{array}$ & 567 \\
\hline
\end{tabular}

Data presented for 81 Costa Rican counties (total number of observations $=567$ ). Standard deviation is presented in parentheses. BOD-1 model assumes 'full flexibility' and 'non-negativity' in the computation of weights, model BOD-2 introduces common weights (all CCI sub-indicators are equally important), and model BOD-3 uses the weights computed via factor analysis. 


\section{Appendix}

Table A1. The County Competitiveness Index (CCI): Variables and pillars

\begin{tabular}{|c|c|c|}
\hline Variable & Sub-index (pillar) & Index \\
\hline 1.1. Electricity consumption growth rate & \multirow{4}{*}{ Local economy } & \multirow{37}{*}{$\begin{array}{l}\text { County } \\
\text { Competitiveness } \\
\text { Index (CCI) }\end{array}$} \\
\hline 1.2. M2 of construction per Km2 & & \\
\hline 1.3. Municipal expenditures per capita & & \\
\hline 1.4. Total exports per worker & & \\
\hline 2.1. Municipal income per capita & \multirow{7}{*}{ Local administration } & \\
\hline 2.2. Municipal non-administrative expenditure per capita & & \\
\hline 2.3. Degree of dependence on public sector transfers & & \\
\hline 2.4. Time to grant patents (days) & & \\
\hline 2.5. Participation in municipal and presidential elections & & \\
\hline 2.6. County road network: Expenditure on roads per $\mathrm{Km}$ & & \\
\hline $\begin{array}{l}\text { 2.7. Number of environmental impact evaluations per } \\
\text { construction permit }\end{array}$ & & \\
\hline 3.1. Percentage of paved road network & \multirow{7}{*}{$\begin{array}{l}\text { Physical and digital } \\
\text { infrastructures }\end{array}$} & \\
\hline 3.2. Houses with access to electricity per Km2 & & \\
\hline 3.3. Percentage of houses with access to drinking water & & \\
\hline 3.4. Percentage of houses with residential telephone & & \\
\hline 3.5. Percentage of houses with access to Internet & & \\
\hline 3.6. 4G mobile network coverage and quality* & & \\
\hline 3.7. 4G global download performance percentage* & & \\
\hline 4.1. Competition index & \multirow{4}{*}{$\begin{array}{l}\text { Business } \\
\text { environment }\end{array}$} & \\
\hline 4.2. Number of financial entities (branches) per Km2 & & \\
\hline 4.3. Activity concentration index & & \\
\hline 4.4. Percentage of exporting companies & & \\
\hline 5.1. English coverage in elementary school & \multirow{6}{*}{ Human capital } & \\
\hline 5.2. Secondary studies enrollment & & \\
\hline 5.3. Tertiary education enrollment & & \\
\hline 5.4. Economically active population & & \\
\hline 5.5. Workers' specialization in services and industry & & \\
\hline $\begin{array}{l}\text { 5.6. Growth rate of formal employment relative to the } \\
\text { economically active population }\end{array}$ & & \\
\hline 6.1. Concentration of exports in high technology sectors & \multirow{3}{*}{ Innovative capacities } & \\
\hline 6.2. Tertiary enrollment (\%) in science and technology & & \\
\hline $\begin{array}{l}\text { 6.3. Rate of education centers (elementary schools and } \\
\text { high schools) with Internet connection }\end{array}$ & & \\
\hline 7.1. Mortality rate caused by infections & \multirow{6}{*}{ Quality of life } & \\
\hline $\begin{array}{l}\text { 7.2. Number of entertainment establishments per 10- } \\
\text { thousand inhabitants }\end{array}$ & & \\
\hline 7.3. Homicide rate (deaths) & & \\
\hline 7.4. Inhabitants per primary health care center (EBAIS) & & \\
\hline 7.5. Robberies and assaults per 10 -thousand inhabitants & & \\
\hline 7.6. Municipal effort in environmental mitigation & & \\
\hline
\end{tabular}

* Before 2016, the reference technology was 2G and 3G. Source: Authors' elaboration based on Ulate et al. (2012). 
Table A2. Factor analysis: Summary results

\begin{tabular}{|l|c|c|c|}
\hline Index number and sub-indexes (pillars) & $\begin{array}{l}\text { Number of } \\
\text { variables }\end{array}$ & $\begin{array}{l}\text { Cronbach’s } \\
\text { alpha }\end{array}$ & $\begin{array}{l}\text { Proportion of } \\
\text { variance explained }\end{array}$ \\
\hline Panel A: Full index & & & \\
\hline County Competitiveness Index (CCI) & 7 & 0.7627 & $58.19 \%$ \\
\hline Panel B: Pillar results & & & \\
\hline Local economy & 4 & 0.6402 & $47.79 \%$ \\
\hline Local administration & 7 & 0.6861 & $53.99 \%$ \\
\hline Physical and digital infrastructures & 7 & 0.8756 & $69.96 \%$ \\
\hline Business environment & 4 & 0.6947 & $52.84 \%$ \\
\hline Human capital & 6 & 0.7360 & $57.22 \%$ \\
\hline Innovative capacities & 3 & 0.7845 & $59.33 \%$ \\
\hline Quality of life & 6 & 0.6742 & $50.72 \%$ \\
\hline
\end{tabular}


Table A3. Performance assessment and results of CCI and BOD model (equation (1)) (ranking is based on the results for the year 2016)

\begin{tabular}{|c|c|c|c|c|c|}
\hline \multirow[b]{2}{*}{$\mathrm{N}$} & \multirow[b]{2}{*}{$\begin{array}{l}\text { Counties } \\
\text { (by province) }\end{array}$} & \multicolumn{2}{|c|}{ Results for 2010} & \multicolumn{2}{|c|}{ Results for 2016} \\
\hline & & $\begin{array}{l}\text { CCI } \\
\text { (ranking) }\end{array}$ & $\begin{array}{l}\text { Eq. (1): } C C I_{i}^{B O D} \\
\text { (ranking) }\end{array}$ & $\begin{array}{l}\text { CCI } \\
\text { (ranking) }\end{array}$ & $\begin{array}{l}\text { Eq. (1): } C C I_{i}^{B O D} \\
\text { (ranking) }\end{array}$ \\
\hline & Panel 1: San Jose & 0.3906 & 0.4922 & 0.3975 & 0.4564 \\
\hline 1 & San José & $0.7342(2)$ & $1.0000(1)$ & $0.7407(1)$ & $1.0000(1)$ \\
\hline 2 & Escazú & $0.5622(4)$ & $0.8544(3)$ & $0.6963(3)$ & $1.0000(1)$ \\
\hline 3 & Curridabat & $0.4882(8)$ & $0.7264(8)$ & $0.5555(5)$ & $0.8378(4)$ \\
\hline 4 & Montes de Oca & $0.6259(3)$ & $0.8403(4)$ & $0.6054(4)$ & $0.8280(5)$ \\
\hline 5 & Santa Ana & $0.4909(7)$ & $0.7710(6)$ & $0.5003(8)$ & $0.7878(6)$ \\
\hline 6 & Goicoechea & $0.4323(16)$ & $0.6157(19)$ & $0.4667(11)$ & $0.6862(10)$ \\
\hline 7 & Desamparados & $0.3451(36)$ & $0.0014(78)$ & $0.4293(15)$ & $0.6366(14)$ \\
\hline 8 & Tibás & $0.5392(5)$ & $0.8354(5)$ & $0.4632(12)$ & $0.6350(15)$ \\
\hline 9 & Moravia & $0.4402(15)$ & $0.5593(30)$ & $0.4491(13)$ & $0.5610(22)$ \\
\hline 10 & Vázquez de Coron & $0.3753(28)$ & $0.4542(50)$ & $0.3529(28)$ & $0.4999(32)$ \\
\hline 11 & Tarrazú & $0.3113(53)$ & $0.4802(45)$ & $0.2996(49)$ & $0.4735(38)$ \\
\hline 12 & Dota & $0.3467(35)$ & $0.5214(36)$ & $0.3014(46)$ & $0.4658(41)$ \\
\hline 13 & Mora & $0.3117(52)$ & $0.4960(42)$ & $0.3013(47)$ & $0.4323(50)$ \\
\hline 14 & Pérez Zeledón & $0.2672(62)$ & $0.4128(57)$ & $0.2891(55)$ & $0.3836(56)$ \\
\hline 15 & Acosta & $0.1890(74)$ & $0.2868(66)$ & $0.2549(64)$ & $0.3664(57)$ \\
\hline 16 & Puriscal & $0.3285(45)$ & 0.4447 (53) & $0.2371(68)$ & $0.3280(62)$ \\
\hline 17 & Aserrí & $0.2346(68)$ & $0.3191(65)$ & $0.2384(67)$ & $0.2821(69)$ \\
\hline 18 & Turrubares & $0.3419(38)$ & $0.2213(71)$ & $0.2048(72)$ & $0.1178(74)$ \\
\hline 19 & León Cortés & $0.2473(65)$ & $0.0010(81)$ & $0.2514(65)$ & $0.0020(77)$ \\
\hline 20 & Alajuelita & $0.2009(73)$ & $0.0020(75)$ & 0.3117 (44) & $0.0011(81)$ \\
\hline & Panel 2: Alajuela & 0.3408 & 0.4585 & 0.3179 & 0.4098 \\
\hline 21 & Atenas & $0.3471(34)$ & $0.5440(31)$ & $0.3917(17)$ & $0.6412(12)$ \\
\hline 22 & Alajuela & $0.4713(11)$ & $0.6163(18)$ & $0.5032(7)$ & $0.6399(13)$ \\
\hline 23 & Poás & $0.3356(42)$ & $0.5155(38)$ & $0.3589(25)$ & $0.5959(18)$ \\
\hline 24 & Grecia & $0.3825(27)$ & $0.5913(24)$ & $0.3775(21)$ & $0.5672(19)$ \\
\hline 25 & San Carlos & $0.3894(22)$ & $0.6155(20)$ & $0.3679(22)$ & $0.5496(24)$ \\
\hline 26 & Naranjo & $0.3889(23)$ & $0.5895(25)$ & $0.3392(34)$ & $0.5435(25)$ \\
\hline 27 & San Mateo & $0.3293(44)$ & 0.4335 (55) & $0.3635(24)$ & $0.5302(27)$ \\
\hline 28 & Valverde Vega & $0.4578(13)$ & $0.6701(11)$ & $0.3321(37)$ & $0.5215(28)$ \\
\hline 29 & Orotina & 0.3847 (24) & $0.6203(17)$ & $0.3391(35)$ & $0.5117(30)$ \\
\hline 30 & Palmares & $0.4438(14)$ & $0.6507(13)$ & $0.3429(31)$ & $0.4733(39)$ \\
\hline 31 & San Ramón & 0.3018 (59) & $0.0014(78)$ & $0.3317(38)$ & $0.3382(60)$ \\
\hline 32 & Upala & $0.1762(79)$ & 0.2837 (67) & $0.1309(80)$ & 0.1867 (73) \\
\hline 33 & Los Chiles & $0.1470(81)$ & $0.0020(75)$ & $0.1624(78)$ & $0.0452(76)$ \\
\hline 34 & Zarcero & 0.3993 (18) & $0.5965(21)$ & $0.2875(56)$ & $0.0020(77)$ \\
\hline 35 & Guatuso & $0.1572(80)$ & $0.1472(74)$ & $0.1402(79)$ & $0.0012(80)$ \\
\hline
\end{tabular}


Table A3. Continued

\begin{tabular}{|c|c|c|c|c|c|}
\hline \multirow[b]{2}{*}{$\mathrm{N}$} & \multirow[b]{2}{*}{$\begin{array}{l}\text { Counties } \\
\text { (by province) }\end{array}$} & \multicolumn{2}{|c|}{ Results for 2010} & \multicolumn{2}{|c|}{ Results for 2016} \\
\hline & & $\begin{array}{l}\text { CCI } \\
\text { (ranking) }\end{array}$ & $\begin{array}{l}\text { Eq. (1): } C C I_{i}^{B O D} \\
\text { (ranking) }\end{array}$ & $\begin{array}{l}\text { CCI } \\
\text { (ranking) }\end{array}$ & $\begin{array}{l}\text { Eq. (1): } C C I_{i}^{B O D} \\
\text { (ranking) }\end{array}$ \\
\hline & Panel 3: Cartago & 0.3473 & 0.5155 & 0.3481 & 0.4824 \\
\hline 36 & Cartago & $0.4624(12)$ & $0.6774(10)$ & $0.4936(9)$ & $0.7219(8)$ \\
\hline 37 & Alvarado & $0.3247(46)$ & $0.4879(43)$ & $0.3420(32)$ & $0.5630(21)$ \\
\hline 38 & La Unión & $0.3956(20)$ & $0.6326(15)$ & $0.3828(19)$ & $0.5029(31)$ \\
\hline 39 & El Guarco & $0.3729(29)$ & $0.5775(27)$ & $0.3664(23)$ & $0.4920(34)$ \\
\hline 40 & Paraíso & $0.2882(60)$ & $0.4609(48)$ & $0.3090(45)$ & $0.4707(40)$ \\
\hline 41 & Jiménez & $0.3667(32)$ & $0.4013(58)$ & $0.2955(51)$ & $0.3876(55)$ \\
\hline 42 & Turrialba & $0.2463(66)$ & $0.3772(60)$ & $0.2955(51)$ & $0.4201(53)$ \\
\hline 43 & Oreamuno & $0.3214(47)$ & $0.5089(40)$ & $0.3001(48)$ & $0.3013(65)$ \\
\hline & Panel 4: Heredia & 0.4110 & 0.6028 & 0.4133 & 0.5779 \\
\hline 44 & Belén & $0.7441(1)$ & $1.0000(1)$ & $0.7090(2)$ & $1.0000(1)$ \\
\hline 45 & Heredia & $0.4917(6)$ & $0.6322(16)$ & $0.5345(6)$ & $0.7548(7)$ \\
\hline 46 & Santo Domingo & $0.4871(10)$ & $0.7254(9)$ & $0.4731(10)$ & $0.7095(9)$ \\
\hline 47 & Flores & $0.4873(9)$ & $0.7410(7)$ & $0.4297(14)$ & $0.6732(11)$ \\
\hline 48 & San Isidro & $0.3589(33)$ & $0.5421(33)$ & $0.3859(18)$ & $0.6271(16)$ \\
\hline 49 & San Pablo & $0.3960(19)$ & $0.6368(14)$ & $0.4192(16)$ & $0.5599(23)$ \\
\hline 50 & San Rafael & $0.3424(37)$ & $0.5342(35)$ & 0.3257 (39) & $0.4918(35)$ \\
\hline 51 & Barva & $0.3205(49)$ & $0.4991(41)$ & $0.3582(26)$ & $0.4630(42)$ \\
\hline 52 & Santa Bárbara & $0.3053(57)$ & $0.4788(46)$ & $0.3173(41)$ & $0.4332(49)$ \\
\hline 53 & Sarapiquí & $0.1769(78)$ & $0.2380(69)$ & $0.1802(75)$ & $0.0661(75)$ \\
\hline & Panel 5: Guanacaste & 0.3336 & 0.4621 & 0.3014 & 0.4371 \\
\hline 54 & Santa Cruz & $0.3699(30)$ & $0.5786(26)$ & $0.3547(27)$ & $0.5635(20)$ \\
\hline 55 & Liberia & $0.4147(17)$ & $0.6668(12)$ & $0.3466(29)$ & $0.5184(29)$ \\
\hline 56 & Abangares & $0.3024(58)$ & $0.3741(61)$ & $0.2934(53)$ & $0.4797(37)$ \\
\hline 57 & Tilarán & $0.3134(51)$ & $0.5111(39)$ & $0.3118(43)$ & $0.4482(43)$ \\
\hline 58 & Carrillo & $0.3384(41)$ & $0.5363(34)$ & $0.2859(57)$ & $0.4460(44)$ \\
\hline 59 & Hojancha & $0.3841(25)$ & $0.5636(29)$ & $0.3406(33)$ & $0.4430(45)$ \\
\hline 60 & Nicoya & $0.3082(55)$ & $0.4463(52)$ & $0.2841(60)$ & $0.4352(48)$ \\
\hline 61 & Cañas & $0.3205(49)$ & $0.5204(37)$ & $0.2666(63)$ & $0.4272(52)$ \\
\hline 62 & Bagaces & $0.3212(48)$ & $0.4376(54)$ & $0.2902(54)$ & $0.4126(54)$ \\
\hline 63 & La Cruz & 0.2571 (63) & $0.0020(75)$ & $0.2217(70)$ & 0.3367 (61) \\
\hline 64 & Nandayure & $0.3395(40)$ & 0.4468 (51) & $0.3203(40)$ & $0.2981(66)$ \\
\hline
\end{tabular}


Table A3. Continued

\begin{tabular}{|l|l|l|l|l|l|}
\hline & & \multicolumn{3}{|l|}{ Results for 2010 } & \multicolumn{2}{l|}{ Results for 2016 } \\
\hline $\mathrm{N}$ & $\begin{array}{l}\text { Counties } \\
\text { (by province) }\end{array}$ & $\begin{array}{l}\text { CCI } \\
\text { (ranking) }\end{array}$ & $\begin{array}{l}\text { Eq. (1): CCI }{ }_{i}^{\text {BOD }} \\
\text { (ranking) }\end{array}$ & $\begin{array}{l}\text { CCI } \\
\text { (ranking) }\end{array}$ & $\begin{array}{l}\text { Eq. (1): CCI } \\
\text { (ranking) }\end{array}$ \\
\hline & Panel 6: Puntarenas & $\mathbf{0 . 3 0 7 3}$ & $\mathbf{0 . 4 6 2 5}$ & $\mathbf{0 . 2 6 2 2}$ & $\mathbf{0 . 3 8 8 7}$ \\
\hline 65 & Garabito & $0.3696(31)$ & $0.5937(23)$ & $0.3823(20)$ & $0.6247(17)$ \\
\hline 66 & Quepos & $0.3900(21)$ & $0.5938(22)$ & $0.3432(30)$ & $0.5426(26)$ \\
\hline 67 & Esparza & $0.3080(56)$ & $0.4777(47)$ & $0.3150(42)$ & $0.4975(33)$ \\
\hline 68 & Puntarenas & $0.3401(39)$ & $0.5422(32)$ & $0.3347(36)$ & $0.4909(36)$ \\
\hline 69 & Montes de Oro & $0.3089(54)$ & $0.4872(44)$ & $0.2845(59)$ & $0.4427(46)$ \\
\hline 70 & Parrita & $0.3337(43)$ & $0.5695(28)$ & $0.2739(62)$ & $0.4286(51)$ \\
\hline 71 & Osa & $0.3839(26)$ & $0.4316(56)$ & $0.2852(58)$ & $0.2898(67)$ \\
\hline 72 & Golfito & $0.2863(61)$ & $0.4552(49)$ & $0.1909(74)$ & $0.2871(68)$ \\
\hline 73 & Coto Brus & $0.2188(70)$ & $0.3417(64)$ & $0.1676(77)$ & $0.2565(70)$ \\
\hline 74 & Corredores & $0.2524(64)$ & $0.3855(59)$ & $0.1770(76)$ & $0.2257(71)$ \\
\hline 75 & Buenos Aires & $0.1886(75)$ & $0.2099(72)$ & $0.1295(81)$ & $0.1891(72)$ \\
\hline & & & & & $\mathbf{0 . 2 9 5 8}$ \\
\hline & Panel 7: Limón & $\mathbf{0 . 2 0 8 5}$ & $\mathbf{0 . 2 2 5 8}$ & $\mathbf{0 . 2 4 2 5}$ & $\mathbf{0 . 2 9})$ \\
\hline 76 & Limón & $0.2430(67)$ & $0.3734(62)$ & $0.2957(50)$ & $0.4361(47)$ \\
\hline 77 & Pococí & $0.2057(72)$ & $0.1579(73)$ & $0.2768(61)$ & $0.3574(58)$ \\
\hline 78 & Siquirres & $0.2305(69)$ & $0.3422(63)$ & $0.2328(69)$ & $0.3543(59)$ \\
\hline 79 & Guácimo & $0.1778(76)$ & $0.2225(70)$ & $0.2474(66)$ & $0.3189(63)$ \\
\hline 80 & Matina & $0.1773(77)$ & $0.2571(68)$ & $0.2076(71)$ & $0.3067(64)$ \\
\hline 81 & Talamanca & $0.2167(71)$ & $0.0014(78)$ & $0.1945(73)$ & $0.0014(79)$ \\
\hline
\end{tabular}


Table A4. Fixed-effects regression results: County competitiveness index and local outcomes

\begin{tabular}{|c|c|c|c|c|}
\hline \multirow[b]{2}{*}{ Independent variables } & \multicolumn{2}{|c|}{$\begin{array}{l}\text { Variation rate in the stock of } \\
\text { businesses (business flow rate) }\end{array}$} & \multicolumn{2}{|c|}{$\begin{array}{l}\text { Variation rate in employment } \\
\text { (workers) }\end{array}$} \\
\hline & $(1)$ & $(2)$ & $(1)$ & $(2)$ \\
\hline CCI (index value) $t-1$ & $\begin{array}{l}0.1918^{*} \\
(1.76)\end{array}$ & $\begin{array}{l}0.1978 \\
(1.33)\end{array}$ & $\begin{array}{l}0.1238 \\
(1.41)\end{array}$ & $\begin{array}{l}0.1314 \\
(1.26)\end{array}$ \\
\hline Population (ln) $t-1$ & & $\begin{array}{l}0.2536 \\
(0.82)\end{array}$ & & $\begin{array}{l}0.0748 \\
(0.27)\end{array}$ \\
\hline $\begin{array}{l}\text { Proportion of extractive } \\
\text { businesses } t-1\end{array}$ & & $\begin{array}{c}-0.5130 \\
(1.15)\end{array}$ & & $\begin{array}{c}-0.4614 \\
(1.15)\end{array}$ \\
\hline $\begin{array}{l}\text { Proportion of construction } \\
\text { businesses } t-1\end{array}$ & & $\begin{array}{c}-1.1581^{* *} \\
(2.01)\end{array}$ & & $\begin{array}{c}-1.4489 * * * \\
(2.77) \\
\end{array}$ \\
\hline $\begin{array}{l}\text { Proportion of retailing } \\
\text { businesses } t-1\end{array}$ & & $\begin{array}{c}-0.8412^{*} \\
(1.86) \\
\end{array}$ & & $\begin{array}{c}-0.8584^{* *} \\
(2.11) \\
\end{array}$ \\
\hline $\begin{array}{l}\text { Proportion of businesses in } \\
\text { service sectors } t-1\end{array}$ & & $\begin{array}{c}-0.9779 * * \\
(2.14) \\
\end{array}$ & & $\begin{array}{c}-0.5099 \\
(1.24) \\
\end{array}$ \\
\hline Time dummies & Yes & Yes & Yes & Yes \\
\hline Intercept & $\begin{array}{l}0.1235^{* * * *} \\
(3.21)\end{array}$ & $\begin{array}{c}-1.7455 \\
(0.52)\end{array}$ & $\begin{array}{l}0.0907 * * * \\
(3.32)\end{array}$ & $\begin{array}{c}-0.0746 \\
(0.22)\end{array}$ \\
\hline F-test & $6.07 * * *$ & $5.10 * * *$ & $4.89 * * *$ & $4.19 * * *$ \\
\hline R2 (within) & 0.0836 & 0.1246 & 0.0685 & 0.1048 \\
\hline Average VIF & 1.56 & 8.80 & 1.56 & 8.80 \\
\hline Observations (counties) & $486(81)$ & $486(81)$ & $486(81)$ & $486(81)$ \\
\hline
\end{tabular}

The time-varying independent variables are lagged one period to avoid potential endogeneity problems. All models include a set of $(t-1)$ time dummies. The proportion of manufacturing firms is the omitted industry category. Values in parentheses are absolute $t$-values, based on robust standard errors adjusted by heteroskedasticity. ${ }^{*}, * *, * *$ indicate significance at the $10 \%, 5 \%$ and $1 \%$, respectively. 
Figure A1. Kernel density distribution for the proposed BOD model (equation (1)) and the model BOD-1 ('full flexibility')

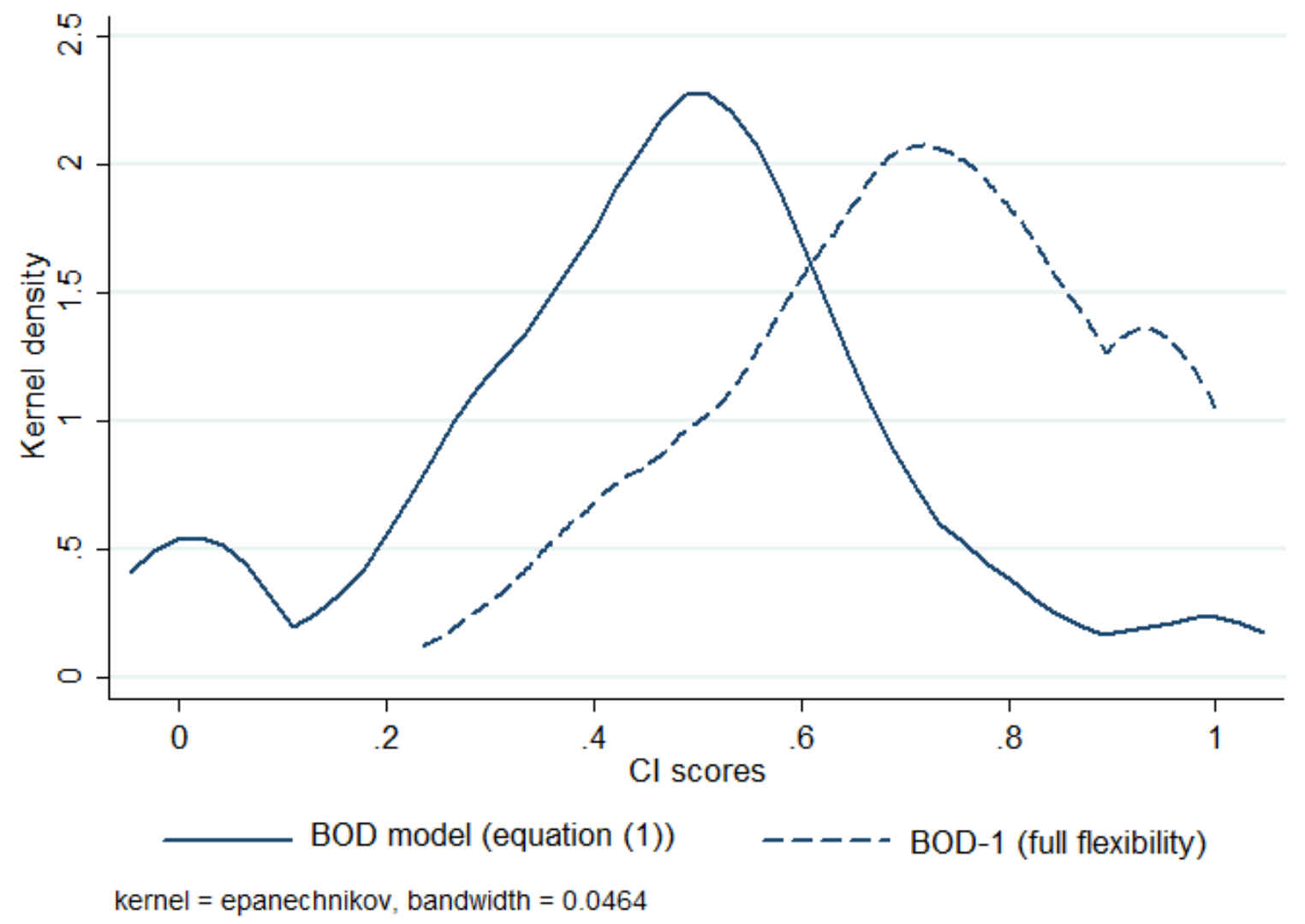

Note: Two-sample Kolmogorov-Smirnov test for equality of distribution functions $=0.5150, p$-value $<0.000$. Source: Authors' elaboration based on the study results. 
Figure A2. Kernel density distribution for the proposed BOD model (equation (1)) and the model BOD-2 (common weight bounds)

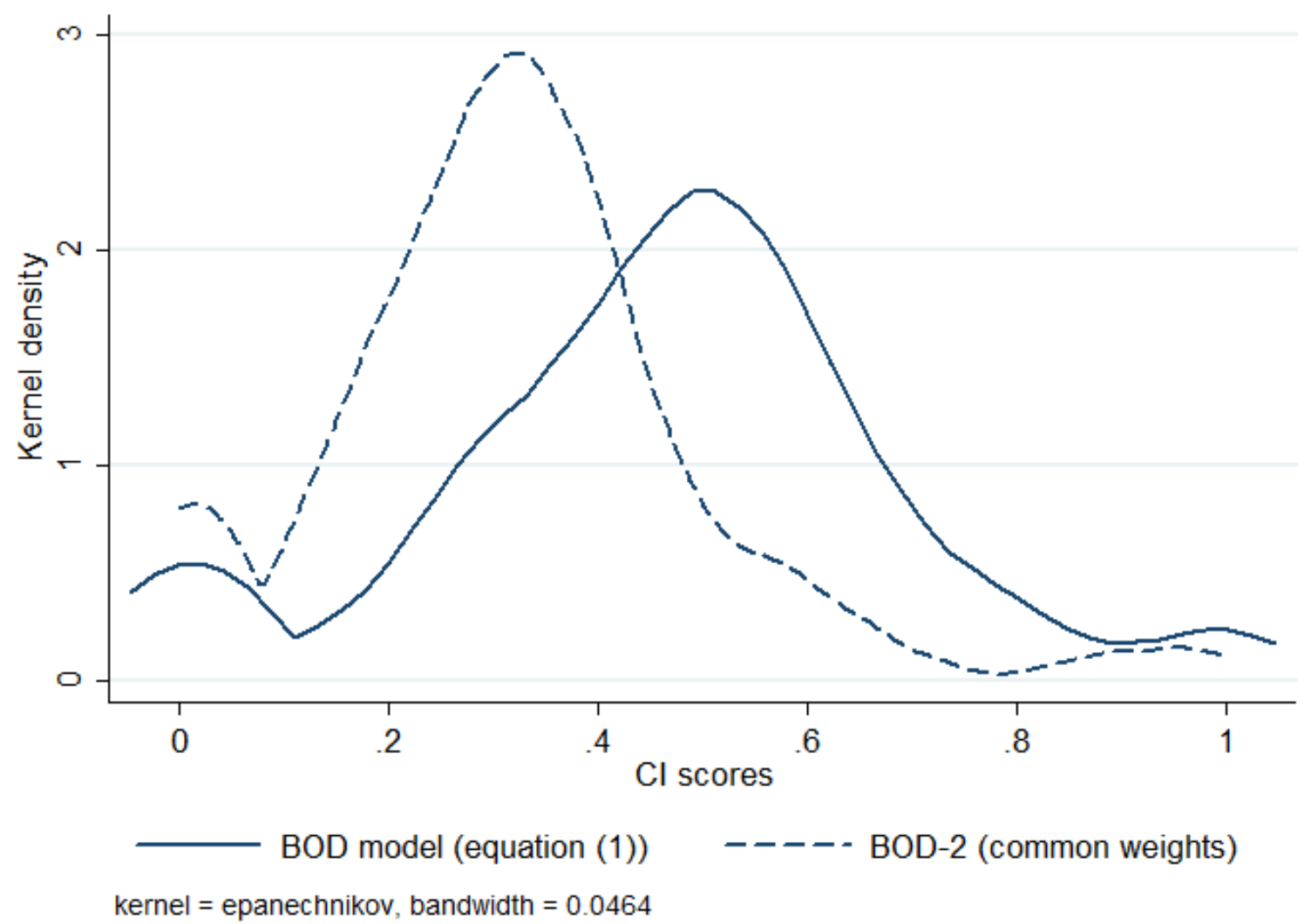

Note: Two-sample Kolmogorov-Smirnov test for equality of distribution functions $=0.4215, p$-value $<0.000$.

Source: Authors' elaboration based on the study results. 
Figure A3. Kernel density distribution for the proposed BOD model (equation (1)) and the model BOD-3 (weights estimated via factor analysis)

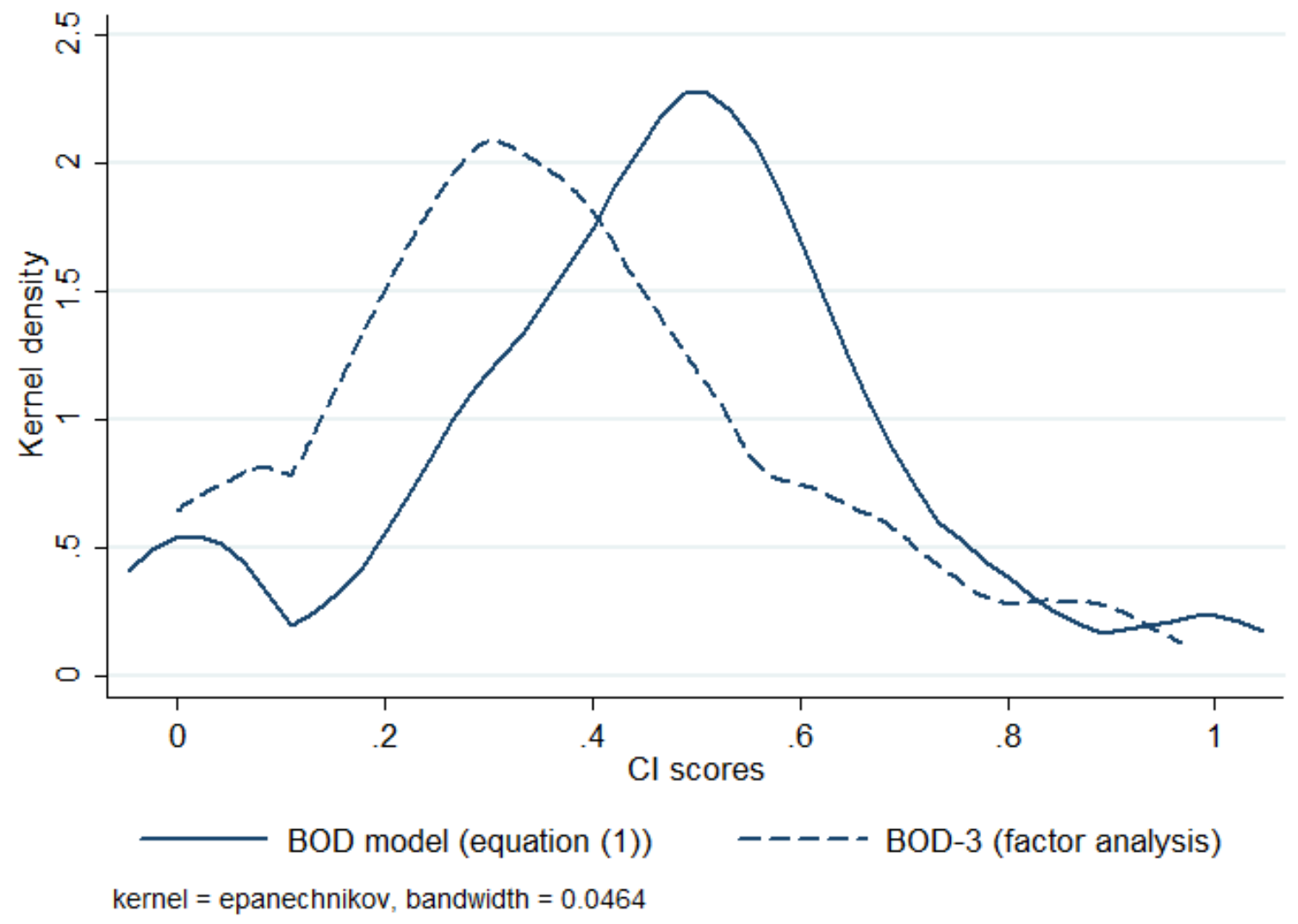

Note: Two-sample Kolmogorov-Smirnov test for equality of distribution functions $=0.2875, p-$ value $<0.000$. Source: Authors' elaboration based on the study results. 